Proceedings of the Prehistoric Society 83, 2017, pp. 213-245 (C) The Prehistoric Society. This is an Open Access article, distributed under the terms of the Creative Commons Attribution licence (http: //creativecommons.org/ licenses/by/4.0/), which permits unrestricted re-use, distribution, and reproduction in any medium, provided the original work is properly cited.

doi:10.1017/ppr.2017.11 First published online 4 October 2017

\title{
Cremation Practices and the Creation of Monument Complexes: The Neolithic Cremation Cemetery at Forteviot, Strathearn, Perth \& Kinross, Scotland, and its comparanda
}

\author{
By GORDON NOBLE ${ }^{1}$ and KENNETH BROPHY ${ }^{2}$ \\ With contributions by DEREK HAMILTON ${ }^{3}$, STEPHANY LEACH ${ }^{4}$ and ALISON SHERIDAN ${ }^{5}$
}

Around the beginning of the $3 r$ millennium cal $B C$ a cremation cemetery was established at Forteviot, central Scotland. This place went on to become one of the largest monument complexes identified in Mainland Scotland, with the construction of a palisaded enclosure, timber structures, and a series of henge monuments and other enclosures. The cemetery was established between 3080 and $2900 \mathrm{cal} B C$, probably in the 30th century cal BC, which is contemporary with the cremation cemetery at Stonehenge. Nine discrete deposits of cremated bone, representing the remains of at least 18 people, were identified. In most instances they were placed within cut features and, in one case, a series of cremation deposits was associated with a broken standing stone. This paper includes the first detailed assessment of the cremated remains at Forteviot and the features associated with the cemetery, and explores how the establishment of this cemetery may have been both a catalyst and inspiration for the elaborate monument building and prolonged acts of remembrance that occurred at this location over a period of almost 1000 years. The paper also outlines the parallels for Forteviot across Britain and, for the first time, draws together the dating evidence (including Bayesian modelling) for this major category of evidence for considering the nature of late 4th/ early $3 r d$ millennium cal $B C$ society. The results and discussion have wide implications and resonances for contemplating the establishment and evolution of monument complexes in prehistoric Britain and beyond.

Keywords: Neolithic, Forteviot, cremation cemetery, monumentality, bone 'skewer' pins, Grooved Ware complex, chronology, radiocarbon dating

\section{INTRODUCTION}

In 2009, a late 4th/early 3rd millennium cal BC cremation cemetery (ie, a cemetery featuring multiple deposits of cremated human remains) was discovered at Forteviot, Perth \& Kinross, central Scotland, during excavations

${ }^{1}$ Department of Archaeology, University of Aberdeen, St Mary's, Elphinstone Road, Aberdeen, AB24 3UF Email: g.noble@abdn.ac.uk

${ }^{2}$ Department of Archaeology, University of Glasgow, Gregory Building, Lilybank Gardens, Glasgow, G12 8QQ

${ }^{3}$ Scottish Universities Environmental Research Centre, Rankine Avenue, Scottish Enterprise Technology Park, East Kilbride, G75 OQF

${ }^{4}$ North Street, Martock, Somerset, TA12

${ }^{5}$ Early Prehistory, National Museums Scotland, Chambers St, Edinburgh, EH1 1JF within a prehistoric monument complex that was first identified by aerial reconnaissance in the 1970s (Fig. 1; St Joseph 1976). The complex at Forteviot includes a Neolithic palisaded enclosure $265 \mathrm{~m}$ in diameter, three henges, a timber circle, penannular enclosures, and multiple pits. The monument complex was the subject of excavations between 2007 and 2010, as part of the Strathearn Environs and Royal Forteviot (SERF) Project (Driscoll et al. 2010). Eight trenches were opened (Fig. 2), focusing on the palisaded enclosure entrance and boundary, two henge monuments, a timber circle, and a double-ditched enclosure (Noble \& Brophy 2011; Brophy \& Noble 2012). This fieldwork revealed a complex sequence of monumentality and related activity extending from the late 4th/early 3rd millennium cal BC through to the Early Bronze Age, demonstrating that 
THE PREHISTORIC SOCIETY
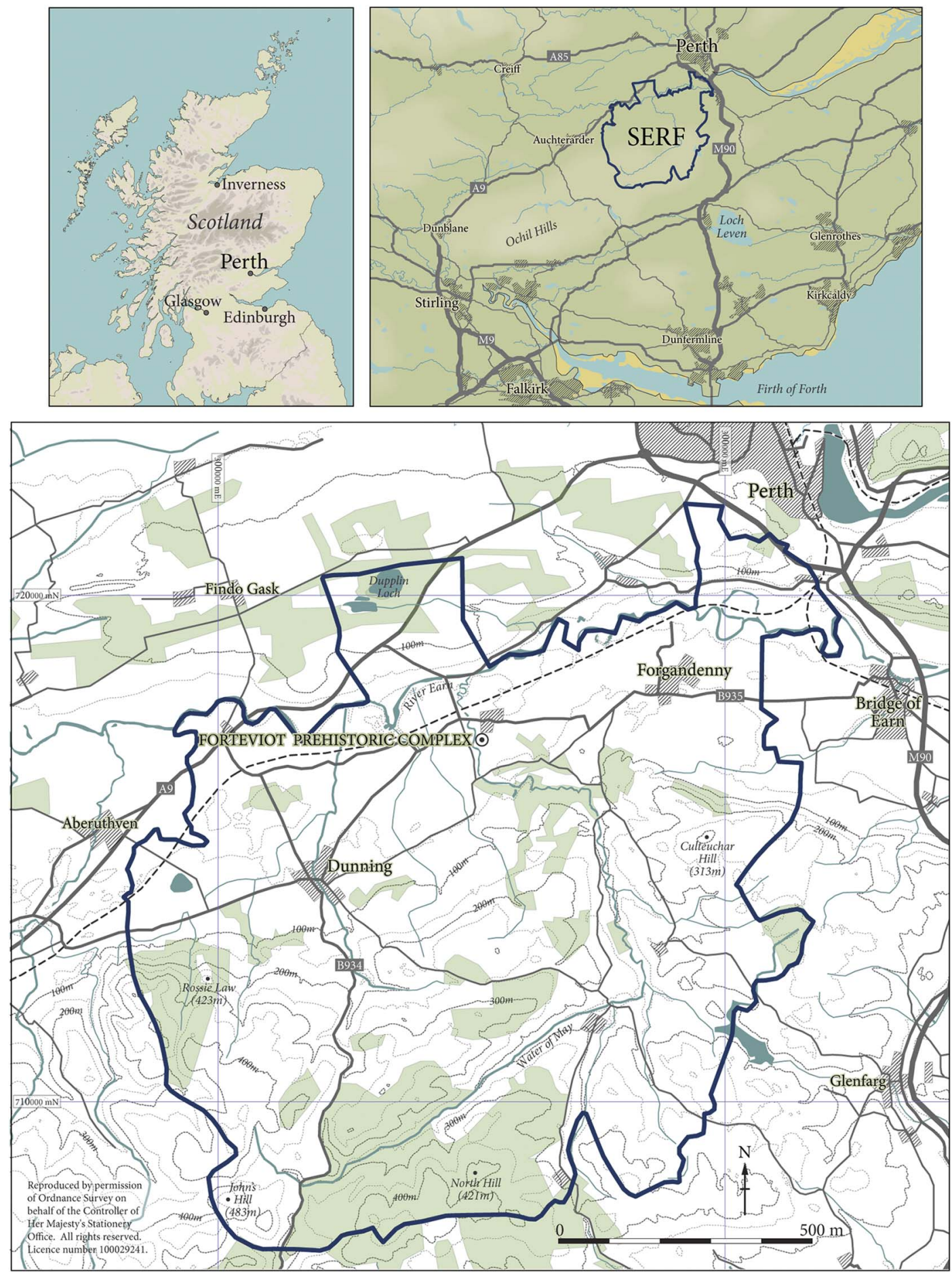

Fig. 1.

Location map showing Forteviot and the study area of the SERF Project (drawn by Lorraine McEwan) 
G. Noble \& K. Brophy. NEOLITHIC CREMATION CEMETERY, FORTEVIOT, PERTH \& KINROSS

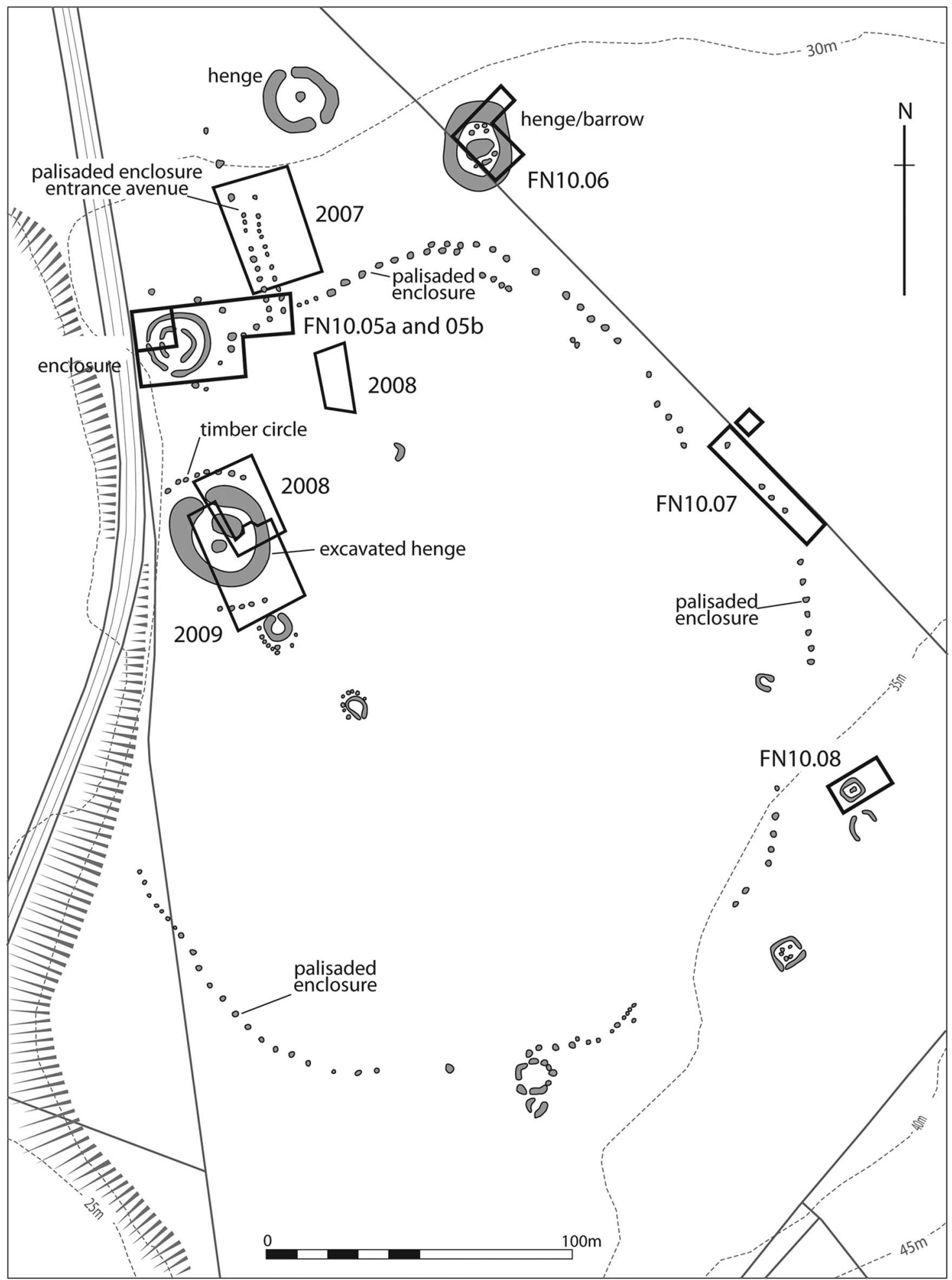

Fig. 2.

The Forteviot cropmarks and trench locations 2007-2010 (drawn by Lorraine McEwan) 
Forteviot endured as a place of ritual, burial, and commemoration for at least a millennium (Brophy \& Noble forthcoming).

The earliest major phase of activity identified at Forteviot was the establishment of a cremation cemetery - the focus of this paper. This cemetery was placed in a location that became enclosed as the 3rd millennium cal BC progressed by, in turn, a palisaded enclosure, a timber circle, and a henge monument. The sequence concluded with an extravagant dagger cist burial at the end of the 3rd millennium cal $\mathrm{BC}$, also within the henge and located c. $10 \mathrm{~m}$ from the cremation cemetery (Noble \& Brophy 2011). Unsurprisingly the cremated remains were disturbed by this intensive later activity, which also included truncation by a large pit dug within the henge interior in the early medieval period (Fig. 3).

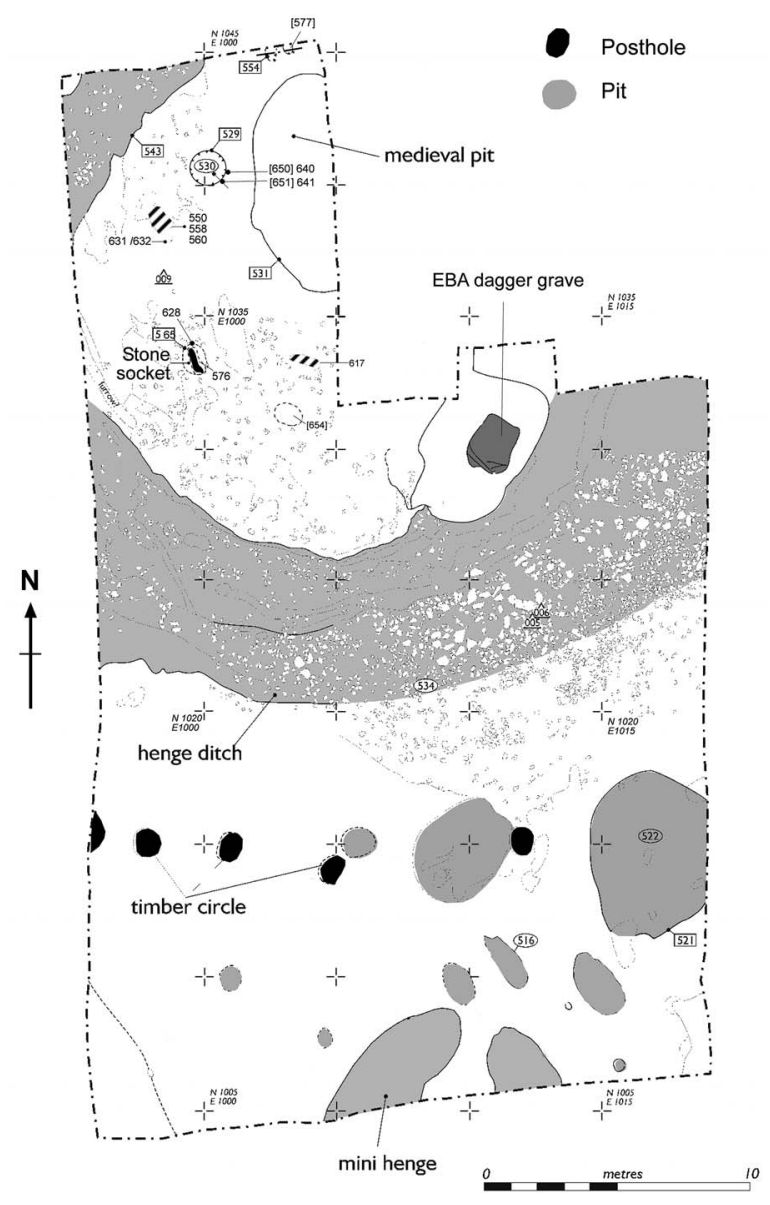

Fig. 3.

Plan of the cremation cemetery and 2009 Henge 1 trench (drawn by Lorraine McEwan \& Alison Sandison)
In this paper we suggest that the cremation cemetery was of considerable importance to the emergence and development of the Forteviot monument complex, marking the establishment of a locale which held special social and religious meaning for well over 1000 years - a place that would retain significance into the historic period when Forteviot became a royal centre (Driscoll 1998). This lengthy sequence resonates with the place-making power of near-contemporary cremation cemeteries from Stonehenge, Wiltshire to Cairnpapple Hill, West Lothian, where cemeteries also marked a primary phase in the development of these places. In order to make this case, our paper will consider the development, chronology, and impact of the cremation cemetery at Forteviot, and place it within its wider context in prehistoric Britain.

Cremation cemeteries are playing an increasingly important role in the discussion of late 4th/early 3rd millennium cal $\mathrm{BC}$ society. Their significance was first recognised during Atkinson's 1940s excavations at Dorchester-on-Thames, Oxfordshire (Atkinson et al. 1951). In 1954, Stuart Piggott (1954, 351-63) defined the 'Dorchester Culture', which he regarded as one of the key cultural groups of his 'secondary Neolithic', a trait of which was cremating the dead. In the coming decades, the notion of a 'Dorchester Culture' receded with the dismantling of culture history models from the 1960s onwards. However, the importance of and the parallels between cremation cemeteries across Britain, many found at regionally important monument complexes, was a topic that was periodically revisited in the coming decades. In the 1970s, Kinnes (1979, fig. 3.3) classified many of these cemeteries as a distinct group in his typological synthesis of round barrows and ring ditches (his Stage E sites). More recent work by Whittle et al. (1992) at Dorchester-onThames; Gibson (2010a; Gibson et al. 2011) at Duggleby Howe, North Yorkshire and Balbirnie, Fife; Parker-Pearson et al. (2009) and Willis et al. (2016) at Stonehenge, alongside the new findings at Forteviot, have reasserted the importance of these cemeteries through new fieldwork and analysis.

\section{DISCOVERY \& EXCAVATION OF THE FORTEVIOT CREMATION CEMETERY}

The cremation cemetery at Forteviot was discovered during the excavation of a Chalcolithic henge monument (known as Forteviot Henge 1). Cremated human remains were found in concentrations, or as 


\section{G. Noble \& K. Brophy. NEOLITHIC CREMATION CEMETERY, FORTEVIOT, PERTH \& KINROSS}

TABLE 1: FEATURES ASSOCIATED WITH THE CREMATION CEMETERY AT FORTEVIOT

\begin{tabular}{|c|c|c|c|}
\hline Feature & Feature type & Cremation deposits & Finds \\
\hline$\overline{[529]}$ & Large pit $1.5 \mathrm{~m}$ diameter, $0.5 \mathrm{~m}$ depth & $\begin{array}{l}\text { Fill (530): MNI } 2 \\
\text { Fill (595): MNI } 2 \\
\text { Fill (596): MNI } 1\end{array}$ & $\begin{array}{l}\text { Deposits (595) \& (596) each } \\
\text { contained a frag. of calcined } \\
\text { bone pin (Table } 2 \text { ) }\end{array}$ \\
\hline [650] & Scoop adjacent to [529] & Fill (640): MNI 1 & $\begin{array}{l}\text { Small pottery vessel } \\
\text { (see Sheridan in text) }\end{array}$ \\
\hline [651] & Scoop adjacent to [529] & Fill (641): MNI 4 & Calcined bone pin frags \\
\hline$(550)$ & Spread & Fragments & \\
\hline$(558)$ & Spread below $(550)$ & MNI 2 & \\
\hline$(560)$ & Spread below (550) & MNI 1 & \\
\hline (631) & Scoop & MNI 2 & \\
\hline (632) & Scoop & MNI 1 & \\
\hline [565] & $\begin{array}{l}\text { Stone socket } 1.2 \mathrm{~m} \text { diameter (pit not } \\
\text { completely excavated so total depth } \& \\
\text { cut profile unknown). Contained large } \\
\text { sandstone slab } 0.8 \mathrm{~m} \text { wide } \& 0.16 \mathrm{~m} \text { thick } \\
\text { surviving to depth of at least } 0.2 \mathrm{~m}\end{array}$ & $\begin{array}{l}\text { Fill (566): MNI } 1 \\
\text { Fill (576): MNI } 3\end{array}$ & Calcined bone pin frags \\
\hline$(628)$ & $\begin{array}{l}\text { Deposit around stone socket [565]. (628) } \\
\text { well-defined \& circular in plan, hinting at } \\
\text { placement within organic vessel }\end{array}$ & MNI 1 & Calcined bone pin frags \\
\hline$(617)$ & Spread & MNI 2 & Calcined bone pin frag. \\
\hline
\end{tabular}

fragmented scatters, across an area of mixed silt deposits measuring $14.5 \mathrm{~m}$ north-south by $9 \mathrm{~m}$ east-west in the western half of the henge interior. A number of areas with distinctive concentrations of burnt bone and charcoal were targeted for excavation, and this revealed formal cremation deposits within cut features set in a rough arc (Fig. 3, and see Table 1). Cremated bones, in smaller quantities, were also found outwith secure contexts and are likely to be the remains of further cremation deposits that were disturbed by later activity as well as modern ploughing. This means that the true extent of the cremation cemetery, and any truncation that may have impacted on it, are unknown, and no obvious boundary such as a ditch was identified. The following discussion of the excavation details is structured by the features within which cremated remains were found (for locations, see Fig. 3); more detailed information will appear in a broader consideration of the Forteviot sequence (Brophy \& Noble forthcoming).

One of the most obvious features of the cremation cemetery when first uncovered was [529], a substantial pit which contained discrete deposits of cremated remains (for a summary of all cremation deposits, see Tables $1 \& 2$ ). Each cremation deposit was circular in plan and so had the appearance of being placed within the pit in an organic container, with stones laid between to separate them. Two adjacent small pits or

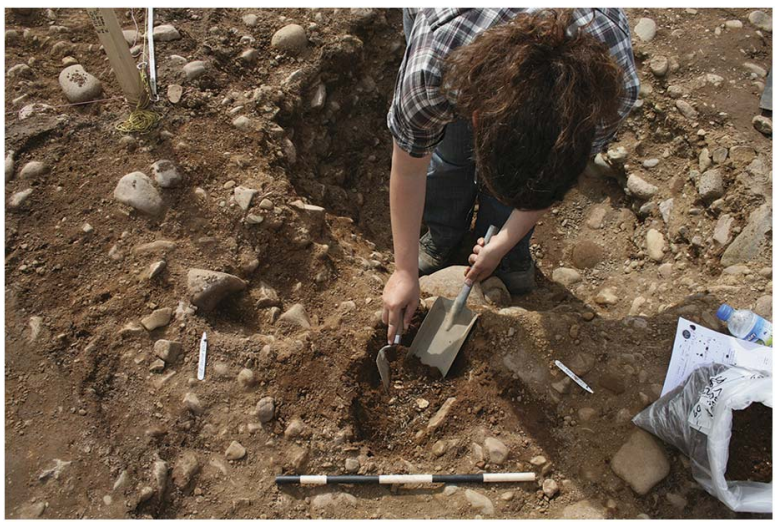

Fig. 4.

Cremation pit [650] under excavation. The excavator is standing in the fully excavated pit [529] @ SERF Project

scoops $[650,651]$ were located immediately to the east of [529], both containing cremation deposits (Fig. 4). One of these, in [650], was accompanied by a small pottery vessel (see Sheridan below). Three concentrations of cremated remains - (550), (558), and (560) were found after initial cleaning within a patch of silt $3 \mathrm{~m}$ to the south-west of the large pit. A further cremation deposit was found closer to the henge ditch in a shallow depression (631/632).

One of the most intriguing features associated with the cemetery was a $1.2 \mathrm{~m}$ diameter sub-circular pit 


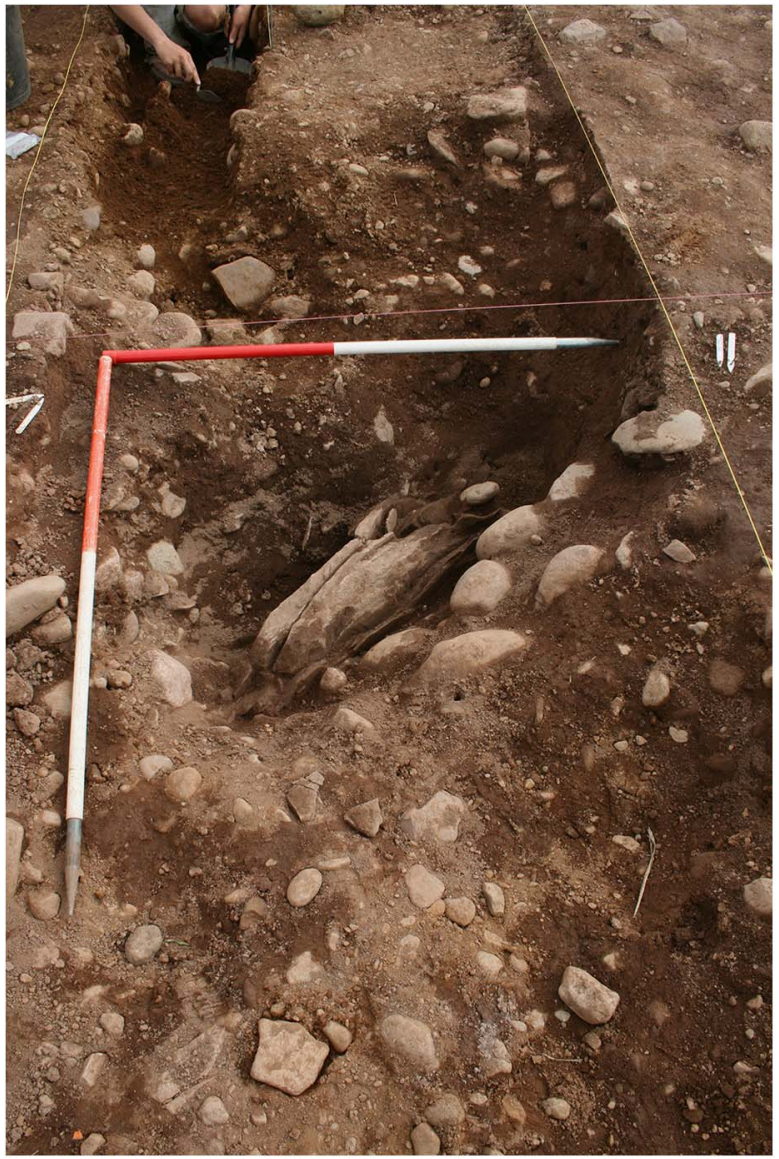

Fig. 5 .

Stone socket with remains of standing stone in feature [565] (C) SERF Project

[565] with a centrally located large, upright (but truncated) sandstone slab. The stone had the appearance of being a standing stone which had been broken in antiquity, with the lower section left in situ (Fig. 5). A series of cremation deposits was identified around the base of this putative standing stone, including one (628) that was well-defined and circular in plan hinting at placement within an organic vessel (Fig. 6).

\section{THE CREMATED REMAINS}

Stephany Leach

The total weight of human cremated bone recovered during the SERF 2009 excavation season was $8722 \mathrm{~g}$, and came from 19 contexts associated with the cremation cemetery (summarised in Table 2; see also

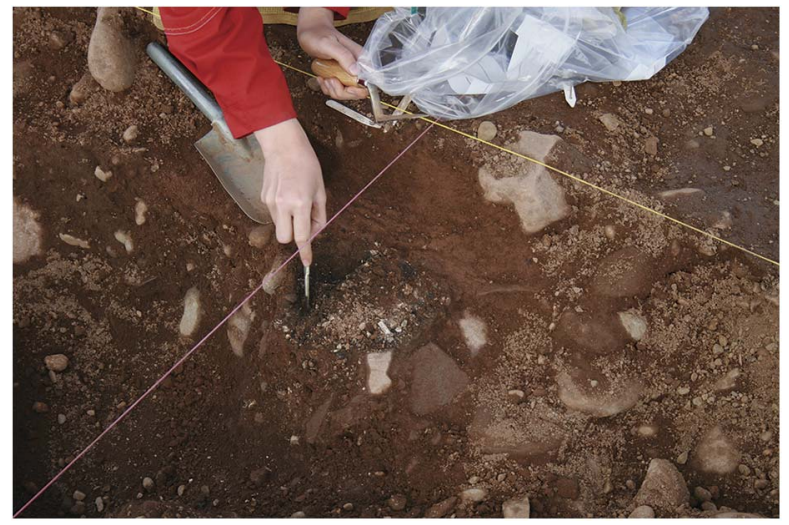

Fig. 6.

Cremation in context (628) under excavation. Note the very regular distribution of the cremation remains suggesting they were held within an organic container of some kind (C) SERF Project

Leach 2012). Following methodologies outlined by Brickley and McKinley (2004), the deposits of cremated remains recovered were sorted according to skeletal categories. Where possible, fragments were identifiable to a specific element, or zone of an element (Knüsel \& Outram 2004), to assist with calculation of minimum number of elements (MNE) and therefore minimum number of individuals (MNI) within the sample. Although the cremated remains were disarticulated, possibly commingled, and extremely fragmentary, the basic principles of age-at-death estimations and sex assignment were applied to the relevant identified fragments, and the bone was also assessed for any signs of pathology or trauma. The weight of recovered cremated bone was also analysed in all cases. The recovered bone weights of the primary depositions identified at Forteviot all fall within the range of those recorded from archaeological contexts (57-3000 g; McKinley 2000, 409), the contexts with the highest number of MNI also exhibiting the highest quantity of cremated bone. McKinley (1993, 285) noted an average weight of $1625.9 \mathrm{~g}$ for modern cremations removing small fragments. Cremated remains were also macroscopically assessed in terms of bone surface colour, level of distortion or shrinkage, and fracture and cracking or fissure patterns to analyse pyre technologies and the biographies of the cremated remains.

The largest number of individual cremation deposits was found in association with large pit [529] and the two smaller adjacent pits $[650,651]$ (see Fig. 3). 
TABLE 2: THE CREMATED BONE DEPOSITS AT FORTEVIOT

\begin{tabular}{|c|c|c|c|c|c|c|c|c|}
\hline Feature & Context & $\begin{array}{l}\text { Sample } \\
\text { no(s) }\end{array}$ & $\begin{array}{l}\text { Weight } \\
\text { (g) }\end{array}$ & $\begin{array}{l}\text { Max. frag. } \\
\text { size } m m\end{array}$ & $\begin{array}{c}\text { Taphonomy: colour, fissures, } \\
\text { erosion etc. }\end{array}$ & Bioprofile details & $\begin{array}{l}\text { Artefact } \\
\text { association }\end{array}$ & Type of deposition \\
\hline $\begin{array}{l}\text { Large pit [529] } \\
\text { containing multiple } \\
\text { cremated deposits }\end{array}$ & $(530)$ & 1049 & 772 & 53 & $\begin{array}{l}\text { Mainly white-light brown, fissures, } \\
\text { transverse, patina, delamination } \\
\text { \& curved transverse fractures, } \\
\text { little evidence of erosion }\end{array}$ & $\begin{array}{l}\text { MNI 2: } 1 \text { young child 2-6 ys; } 1 \\
\text { adult - sex undetermined but } \\
\text { medium-robust bone frags } \\
\text { present, cranial sutures } \\
\text { unfused where present, more } \\
\text { indicative of young-middle } \\
\text { adult }\end{array}$ & $\begin{array}{l}\text { None, blue/ } \\
\text { green stain on } \\
\text { cranial bones }\end{array}$ & Burial \\
\hline $\begin{array}{l}\text { Large pit [529] } \\
\text { containing multiple } \\
\text { cremated deposits }\end{array}$ & $(595)$ & $\begin{array}{l}1040 \\
1046\end{array}$ & 812 & 47 & $\begin{array}{l}\text { Pale grey-white, range of fractures } \\
\text { as }(530) \text {, slight erosion on few } \\
\text { fragments, mainly lacked erosion }\end{array}$ & $\begin{array}{l}\text { MNI 2: } 1 \text { older infant/young } \\
\text { child; } 1 \text { adult - robust, } \\
\text { middle adult? }\end{array}$ & Bone pin frag. & Burial \\
\hline $\begin{array}{l}\text { Large pit [529] } \\
\text { containing multiple } \\
\text { cremated deposits }\end{array}$ & $(596)$ & 1053 & 106 & 34 & $\begin{array}{l}\text { Mostly grey-white, but some black } \\
\text { trabecular frags, mostly transverse } \\
\text { fractures, some erosion }\end{array}$ & $\begin{array}{l}\text { MNI 1: older child/adolescent } \\
\text { or v. gracile adult based on } \\
\text { bone frag. proportions only }\end{array}$ & Bone pin frag. & $\begin{array}{l}\text { Burial? } \\
\text { disturbed? }\end{array}$ \\
\hline $\begin{array}{l}\text { Small pit [650] cutting } \\
\text { [529] }\end{array}$ & $(640)$ & 1067 & 74 & 25 & $\begin{array}{l}\text { Black, grey to white for cranial frags, } \\
\text { postcranial dark brown trabecular, } \\
\text { white cortical, some erosion, range } \\
\text { of fractures as }(530)\end{array}$ & $\begin{array}{l}\text { MNI 1: young child, } \\
\text { incomplete representation of } \\
\text { skeletal regions, but cranial } \\
\& \text { postcranial present \& all } \\
\text { frags consistent with this } 1 \\
\text { individual }\end{array}$ & None & $\begin{array}{l}\text { Burial? } \\
\text { disturbed? }\end{array}$ \\
\hline $\begin{array}{l}\text { Small pit [651] cutting } \\
\text { [529] }\end{array}$ & $(641)$ & 1070 & 2004 & 84 & $\begin{array}{l}\text { Pale grey-white, range of fractures } \\
\text { indicative of fleshed cremation, } \\
\text { little evidence of erosion, } \\
\text { dentition \& small elements } \\
\text { indicate meticulous collection for } \\
\text { deposition }\end{array}$ & $\begin{array}{l}\text { MNI 4: } 2 \text { adults }-1 \text { robust, } 1 \\
\text { gracile; } 2 \text { children }-1 \text { older } \\
\text { child, } 1 \text { younger child; } \\
\text { developmental stress in child's } \\
\text { dentition, possible perimortem } \\
\text { trauma on adult cranium }\end{array}$ & Bone pin frags & Burial \\
\hline $\begin{array}{l}\text { Upper silt deposits } \\
\text { above }(558) \& \\
(560)\end{array}$ & $(550)$ & 1016,013 & 8 & 34 & $\begin{array}{l}\text { White - fissures and most } \\
\text { fragments heavily eroded }\end{array}$ & $\begin{array}{l}\text { Only a few fragments of bone: } \\
\text { robust cortical bone and one } \\
\text { gracile phalanx (finger bone) }\end{array}$ & None & $\begin{array}{l}\text { Disturbance } \\
\text { residue? }\end{array}$ \\
\hline Cremation (558) & $(558)$ & $\begin{array}{r}1013 \\
1044\end{array}$ & 417 & 86 & $\begin{array}{l}\text { Grey-white, sample } 1013 \& \text { SF } 37 \\
\text { far more fragmented \& eroded } \\
\text { than } 1044 \text { main sample, range of } \\
\text { fractures indicative of thermal } \\
\text { alteration of fleshed remains }\end{array}$ & $\begin{array}{l}\text { MNI 2: NB: almost all frags } \\
\text { indicate robust adult, prob. } \\
\text { young adult as sutures open } \\
\& \text { bone dense; only } 1 \text { bone } \\
\text { frag., incomplete child size } \\
\text { hand phalanx indicates } \\
\text { presence of a child }\end{array}$ & None & $\begin{array}{l}\text { Burial, disturbance/ } \\
\text { admixture }\end{array}$ \\
\hline Cremation (560) & $(560)$ & $\begin{array}{l}\text { ?no. } \\
\text { missing }\end{array}$ & 370 & 54 & $\begin{array}{l}\text { White, heavily eroded fragments, } \\
\text { similar to material from } \\
\text { disturbed contexts, yet weight \& } \\
\text { element representation more } \\
\text { suggestive of primary burial, } \\
\text { perhaps with some disturbance } \\
\text { or redeposition indicated; this } \\
\text { assemblage exhibits a different } \\
\text { taphonomic history to other } \\
\text { primary depositions }\end{array}$ & $\begin{array}{l}\text { MNI 1: fragmented bones } \\
\text { consistent with middle adult } \\
\text { of medium build, indicated } \\
\text { by partial closure of cranial } \\
\text { sutures \& dense bone }\end{array}$ & None & $\begin{array}{l}\text { Disturbed burial or } \\
\text { redeposited/ } \\
\text { secondary } \\
\text { deposition }\end{array}$ \\
\hline
\end{tabular}


TABLE 2: CONTINUED

\begin{tabular}{|c|c|c|c|c|c|c|c|c|}
\hline Feature & Context & $\begin{array}{l}\text { Sample } \\
n o(s)\end{array}$ & $\begin{array}{l}\text { Weight } \\
(g)\end{array}$ & $\begin{array}{l}\text { Max. frag. } \\
\text { size } \mathrm{mm}\end{array}$ & $\begin{array}{l}\text { Taphonomy: colour, fissures, } \\
\text { erosion etc. }\end{array}$ & Bioprofile details & $\begin{array}{c}\text { Artefact } \\
\text { association }\end{array}$ & Type of deposition \\
\hline $\begin{array}{l}\text { Cremation deposits } \\
(631 / 632)\end{array}$ & $(631)$ & $\begin{array}{l}1052 \\
1056\end{array}$ & 654 & 52 & $\begin{array}{l}\text { Grey-white, some erosion, fissures } \\
\& \text { fractures consistent with high } \\
\text { level of thermal alteration, most } \\
\text { regions of skeleton represented } \\
\text { but collection does not appear as } \\
\text { meticulous compared to other } \\
\text { deposits or some disturbance/ } \\
\text { redeposition indicated }\end{array}$ & $\begin{array}{l}\text { MNI 2: young adult - dense } \\
\text { bone, open sutures, of } \\
\text { medium build; } 1 \text { older child, } \\
\text { only partially represented - } \\
\text { disturbance? }\end{array}$ & None & $\begin{array}{l}\text { Disturbed primary } \\
\text { burial deposit? }\end{array}$ \\
\hline $\begin{array}{l}\text { Cremation deposits } \\
(631 / 632)\end{array}$ & $(632)$ & 1057 & 93 & 29 & $\begin{array}{l}\text { Dark grey-white, fissures \& } \\
\text { fractures consistent with thermal } \\
\text { alteration, little erosion. Dark } \\
\text { brown/black spotting, probably } \\
\text { manganese staining from } \\
\text { depositional environment }\end{array}$ & $\begin{array}{l}\text { MNI 1: adult, likely associated } \\
\text { with (631) - few frags } \\
\text { unrepresentative of primary } \\
\text { deposit of cremated } \\
\text { individual }\end{array}$ & None & $\begin{array}{l}\text { Associated with } \\
\text { (631) }\end{array}$ \\
\hline Stone socket [565] & $(566)$ & & 48 & 32 & $\begin{array}{l}\text { Dark brown-white, some erosion, } \\
\text { transverse, curved transverse, } \\
\text { stepped, \& patina fractures } \\
\text { indicate high degree of thermal } \\
\text { alteration of fleshed remains }\end{array}$ & $\begin{array}{l}\text { MNI 1: few frags only, not } \\
\text { complete representation, } \\
\text { cranial sutures partial } \\
\text { closure indicative of middle } \\
\text { adult, robust long bone frags }\end{array}$ & Bone pin frag. & $\begin{array}{l}\text { Disturbance } \\
\text { residue? }\end{array}$ \\
\hline Stone socket [565] & $(576)$ & $\begin{array}{l}1027 \\
1048\end{array}$ & 1945 & 52 & $\begin{array}{l}\text { Light brown-white, approx. half } \\
\text { assemblage exhibited moderate } \\
\text { erosion, other half lacked } \\
\text { erosion, thermal related } \\
\text { fractures, but comparatively less } \\
\text { fragmented than other } \\
\text { assemblages in this area }\end{array}$ & $\begin{array}{l}\text { MNI 3: } 2 \text { adults }-1 \text { robust, } 1 \\
\text { gracile; } 1 \text { older child, most } \\
\text { regions of skeleton } \\
\text { represented, subadult } \\
\text { material underrepresented }\end{array}$ & Bone pin frag. & $\begin{array}{l}\text { Possible multiple } \\
\text { burial, disturbed, } \\
\text { or single } \\
\text { deposition with } \\
\text { disturbance/ } \\
\text { admixture }\end{array}$ \\
\hline $\begin{array}{l}\text { Cremation within } \\
\text { organic vessel in } \\
\text { association with } \\
\text { stone socket [565] }\end{array}$ & $(628)$ & 1050 & 212 & 34 & $\begin{array}{l}\text { Light brown-white, little evidence } \\
\text { of erosion, fracture pattern as } \\
(566)\end{array}$ & $\begin{array}{l}\text { MNI 1: young adult, long } \\
\text { bones fused, open cranial } \\
\text { sutures, gracile build, not all } \\
\text { areas of the skeleton } \\
\text { represented }\end{array}$ & None & $\begin{array}{l}\text { Found within vessel } \\
\text { outline, disturbed } \\
\text { deposit or } \\
\text { minimal } \\
\text { collection of } \\
\text { remains? }\end{array}$ \\
\hline Cremation (617) & $(617)$ & 1041 & 1144 & 39 & $\begin{array}{l}\text { Light grey-white, extensive fissures } \\
\& \text { thermal related fractures, } \\
\text { moderate degree of erosion }\end{array}$ & $\begin{array}{l}\text { MNI 2: } 1 \text { gracile adult; } 1 \text { older } \\
\text { child or adolescent }\end{array}$ & $\begin{array}{l}\text { Bone pin frags } \\
\& \text { blue/green } \\
\text { spot staining }\end{array}$ & Possible dual burial \\
\hline
\end{tabular}




\section{G. Noble \& K. Brophy. NEOLITHIC CREMATION CEMETERY, FORTEVIOT, PERTH \& KINROSS}

In total, the MNI estimate represented in the cremation deposits within and around large pit [529] is $8-10$ individuals, comprising the remains of four adults, including young and middle-aged adults, one very young child or older infant, one adolescent, and 2-4 children. In terms of notable features, the deposits from context (641) represent the largest quantity of cremated remains recovered from a single context in the cemetery. Dentition relating to the subadults in this context exhibited a developmental stress indicator in the form of linear enamel hypoplasia, often associated with weaning stress (Roberts \& Cox 2003). Another notable feature is the presence of a possible fracture in an adult cranial fragment in context (640) on the frontal region of the cranial vault. The outline, morphology, and fracture surface - the smoothness, colouration, and linear trajectory - combined indicate the presence of a perimortem (occurring around the time of death) trauma. The characteristics are indicative of a radiating fracture, commonly the result of blunt force injury to the cranium (Gurdjian et al. 1950; Kaufman et al. 1997; Byers 2005). However, as the remains have been subject to intensive fire and recovered in a fragmentary and incomplete state, identification remains tentative.

Contexts (558), (560), and (631/632) also produced substantial quantities of cremated bone indicative of the primary deposition of cremated remains, with a MNI of five, both adults and children. The remains from (560) have a more 'bleached' or weathered/ eroded quality indicative of a different taphonomic history to other primary deposits identified within the cremation cemetery. Variation in post-depositional environment or a delay in deposition of the cremated remains of this individual may be indicated. The quantity of cremated bone in relation to the primary deposits identified in this area is smaller than those recovered from large pit [529]. The assemblage from this area also exhibited a slightly higher level of surface erosion and fragmentation. This may be due to an increased level of disturbance of these deposits, a harsher post-depositional environment, pyre efficiency, or even weather conditions (Alison Sheridan pers. comm.), or this may relate to the level of effort made during collection of material from the pyre.

Further south, cremation deposit (628) was probably contained within an organic container of some kind (Fig. 6). The total weight of human bone for this deposit is $212 \mathrm{~g}$, which is rather underweight for a primary burial, but within the normal range for archaeological cremation deposits. Context (576) contained a discrete cremation deposit in the silt spread around standing stone socket [565]. This context produced almost two-thirds of the bone assemblage recovered from this area, one of the highest concentrations of cremated bone found on site, with a MNI of three represented. Approximately 50\% of the bone fragments exhibit a degree of surface erosion. This implies some level of disturbance or a differential taphonomic history for half of this assemblage. Context (566), also from around stone socket [565], contained the disturbed remains of a cremation including a bone pin fragment. Finally, cremation deposit (617) represented a MNI of two buried with three bone pins.

In summary, a total of $8722 \mathrm{~g}$ of cremated bone was recovered. The calculated minimum estimate of individuals for the sampled area of the cemetery is 18: 11 adults and seven subadults. Due to the high degree of fragmentation and comingling of remains, it was not possible to assign sex to any of the adult remains with a high enough degree of certainty. However, general build was noted for the adults within this death assemblage and a range of robust to gracile bones was noted. Although these results are based on a sample gained from what may have been a larger cemetery, and post-depositional disturbance of remains is indicated, a broad demographic range is represented. The range of this constructed age profile, including young and older children, adolescent and young to middle adult individuals, suggests this place of burial was not the preserve of a specific demographic group, but generally reflects the death profile of a community (excluding the very young). Neonates and mature adults were absent. However, this may well be due to the adverse effects of the cremation, recovery, and post-depositional environment rendering their remains much less visible.

The cremated bone exhibited a high degree of thermal alteration; most of the fragments were highly calcined or oxidised, as indicated by the pale colouration of the bone. Fracture patterns, in particular the curved transverse fractures or 'muscle shrinkage lines', indicate the deceased were placed on the pyre while still fully fleshed. The evidence thus indicates an efficient pyre with sufficient resources to allow for lengthy periods of burning at high temperatures. The presence of small fragments of teeth and finger and toe bones implies a meticulous level of care during the 
time-consuming collection of remains from the pyre site for deposition. McKinley (1995, 459) noted a similar efficiency in the cremation process and thorough collection for deposition of remains at Stonehenge, which is interesting in light of the parallels between these two sites (see below). Similar levels of collection have been noted in the primary cremation deposits of Bronze Age barrows with lesser quantities identifiable in 'satellite' depositions (ibid.).

\section{THE BONE PINS}

Stephany Leach \& Alison Sheridan

Sixteen calcined fragments of worked bone pins from six contexts were identified within the cremated bone assemblage (Table 3). Refitting of conjoining fragments reduced the total to 13 , and it is clear that, in fact, eight or nine pins are represented. The pins are long and slender, tapering from a rounded, bulbed head to what would probably have been a fairly sharp point (Fig. 7); they are of a type known as 'skewer' pins (Atkinson et al. 1951, 72). In all but two fragments, the shaft is circular in cross-section. The bestpreserved pin, No. 1, would have had a length in excess of $125 \mathrm{~mm}$, probably around $150 \mathrm{~mm}$. The thickness of the bulbed heads (as shown by pin Nos $1,2 \& 4$ ) ranges from $6.3 \mathrm{~mm}$ to $7.3 \mathrm{~mm}$. The pins are made from compact, solid bone and their surfaces have been carefully smoothed and polished. The bone has not been identified to a species or body part. The distribution of the pin fragments among the deposits of cremated remains is summarised in Table 3 . A strong association with primary deposits was indicated, with only two fragments recovered from disturbed contexts.

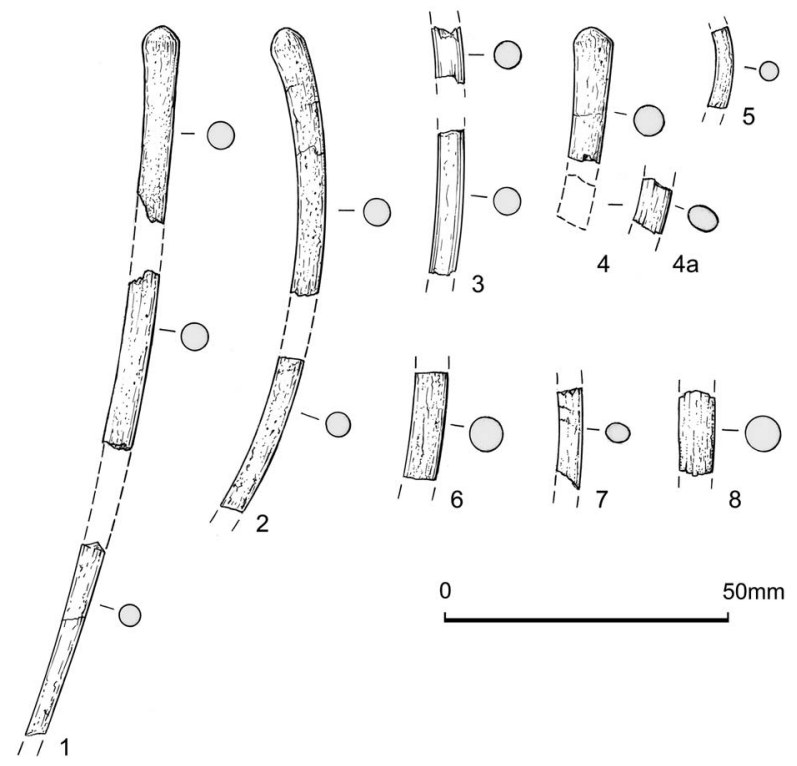

Fig. 7.

Bone pins from Forteviot (drawn by Marion O’Neil)

TABLE 3: THE BONE PINS FROM FORTEVIOT

\begin{tabular}{|c|c|c|c|c|c|c|c|c|}
\hline $\begin{array}{l}\text { Pin } \\
\text { no. }\end{array}$ & Feature & Context & No. frags & $\begin{array}{c}\text { Shaft diameter } \\
(\mathrm{mm})\end{array}$ & $\begin{array}{c}\text { Bulb diameter } \\
(\mathrm{mm})\end{array}$ & MNI & Age & $\begin{array}{c}\text { Primary or disturbed } \\
\text { context }\end{array}$ \\
\hline 1 & Pit [651] & (641) & 9 (now 7 , & 5.5 & 6.3 & 4 & 2 adult, & Primary \\
\hline 1 & & & from refits) & 5.5 & & & 2 subadult & \\
\hline 1 & & & & 4.0 & & & & \\
\hline 1 & & & & 4.0 & & & & \\
\hline 2 & & (641) & & 5.5 & 6.5 & & & \\
\hline 2 & & & & 5.4 & & & & \\
\hline 2 & & & & 4.4 & & & & \\
\hline 3 & & (641) & & 5.2 & & & & \\
\hline 3 & & & & 5.0 & & & & \\
\hline 4 & Spread & (617) & 3 (now 2, & 5.8 & 7.3 & 2 & 1 adult, & Primary \\
\hline 4 & & & from refits) & 5.8 & & & 1 subadult & \\
\hline $4 a$ & & & & 5.5 & & & & \\
\hline 5 & Pit [529] & (595) & 1 & 4.5 & & 2 & $\begin{array}{l}1 \text { adult, } \\
1 \text { subadult }\end{array}$ & Primary \\
\hline 6 & Pit [529] & (596) & 1 & 6.5 & & 1 & 1 subadult & Disturbed \\
\hline 7 & $\begin{array}{l}\text { Standing stone } \\
\text { socket [565] }\end{array}$ & (576) & 1 & 5.5 & & 2 & $\begin{array}{l}1 \text { adult, } \\
1 \text { subadult }\end{array}$ & Primary \\
\hline 8 & $\begin{array}{l}\text { Standing stone } \\
\text { socket [565] }\end{array}$ & (566) & 1 & 3.4 & & 1 & 1 adult & Disturbed \\
\hline
\end{tabular}




\section{G. Noble \& K. Brophy. NEOLITHIC CREMATION CEMETERY, FORTEVIOT, PERTH \& KINROSS}

A clue as to the original function of the pins is provided by the fact that all of the fragments are calcined, indicating they accompanied the deceased on the pyre, probably to fasten some kind of funerary garment. Thermal alteration has made the fragments white, hard, and brittle, with some showing cracking; additionally, the curvature evident on some fragments (especially pin No. 5) could well have developed during the cremation process rather than being an original design feature (contra Montague 1995, 409), since experimental cremation by one of the authors (AS) has demonstrated that long, straight, slender pins of bone or antler can curve on the pyre.

Bone skewer pins dating to the Neolithic - as opposed to their Early Bronze Age counterparts - are relatively rare and few have been found since Atkinson et al. (1951, 142-4) produced their list (note that this includes some thicker pins from Skara Brae and Quoyness which should arguably be excluded). Pins are usually associated with deposits of cremated human remains and calcined, as in the ring ditch complex at Dorchester-on-Thames (ibid., 4, 24; Whittle et al. 1992, 151); the Aubrey Holes at Stonehenge (Montague 1995, 409; Parker Pearson et al. 2009; Parker Pearson 2012, 319, 321); the Neolithic round barrow at Duggleby Howe (Gibson et al. 2011); and Cairnpapple Hill (Piggott 1948, 101). In particular, the Stonehenge material, described by Montague (1995), displays striking similarities in form and dimensions to the Forteviot pins. The maximum, minimum, and average shaft diameters of the pins recovered from Stonehenge $(4.0-6.9 \mathrm{~mm}$, and $5.3 \mathrm{~mm}$ respectively) are almost identical to the Forteviot pin dimensions. Montague (ibid.) considered the Stonehenge pins were possibly derived from long bone shafts of cattle or red deer. Some of the pin fragments at Stonehenge also exhibited a degree of curvature, similar to the Forteviot fragments; Montague argues that this was their original morphology as opposed to warping and twisting caused by thermal alteration (ibid., 409; but see also above). While most Neolithic skewer pins have been found in a calcined state, there is one example of an unburnt pin from Duggleby Howe (Gibson \& Bayliss 2009, 49). This was found behind the back of an unburnt, tightly-contracted adult male skeleton (Burial C); the skeleton has been dated to $3015-2895 \mathrm{cal} \mathrm{BC}$ (95\% probability; GrA-33102; ibid., 68). This individual seems to have been interred before the round mound was erected; in contrast, the three calcined skewer pins associated with cremated remains
(Cremations 4, 20/10, \& 30) were found in the primary mound, and Gibson has argued convincingly that these belong to the first quarter of the 3rd millennium cal BC (ibid., 39).

The fact that the number of pins found at Forteviot (eight or nine) is far smaller than the estimated number of individuals present (18) echoes findings from Dorchester-on-Thames and Cairnpapple, and suggests only some individuals were buried with pins, or in some cases wooden pins were used and burnt on the pyre. At Dorchester-on-Thames Site 2, age differentiation was apparent, with Whittle et al. (1992) noting bone skewer pins tended only to be associated with adults (cf. Garwood \& Barclay 2011, 401). That the Forteviot pins were not exclusively associated with adults is suggested by the evidence from context (641), where three pins were found with two adults and two children.

\section{SMALL POTTERY VESSEL}

Alison Sheridan

Eight sherds and six fragments, constituting around $90 \%$ of a very small, hemispherical, cup-like pot, were found associated with the cremated remains of a child in truncated pit [650] (Fig. 8). The pot had been burnt, and all constituent fragments are soft and abraded. The rim is upright and gently pointed, and the body tapers to a slightly flattened round base. The rim diameter is $c .56 \mathrm{~mm}$, and the vessel has an estimated height of $38 \mathrm{~mm}$; maximum wall thickness is $9 \mathrm{~mm}$. The pot was made by moulding a single lump of clay

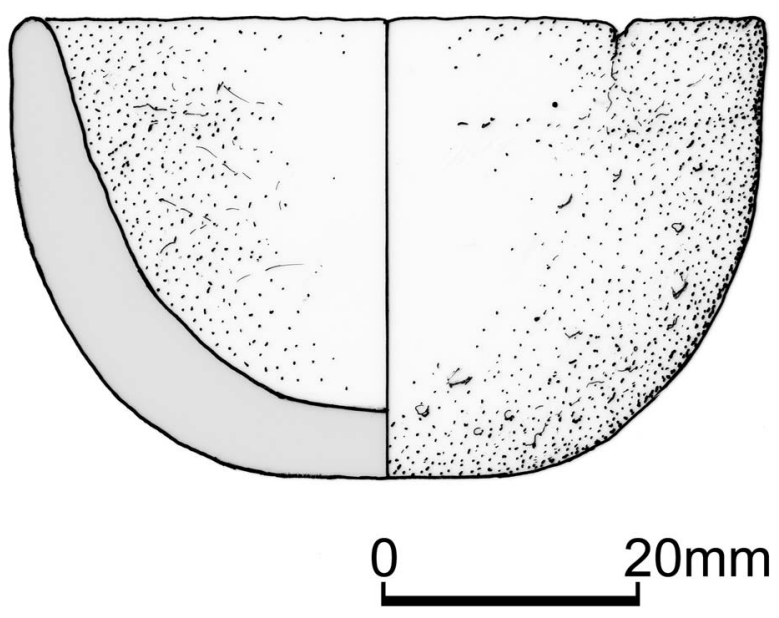

Fig. 8.

Pottery vessel accompanying cremated remains of a child from feature [650] (drawn by Marion O’Neil) 
(ie, as a pinch pot), rather than by using coils of clay, and the surfaces are slightly uneven. The exterior is a buff and light brown colour; the core, buff, and the interior, buff and light pink; in other words, the pot had been thoroughly oxidised. Inclusions are sparse (c. $3-5 \%$ in density) and comprise sub-angular and rounded fragments of stone, up to $3 \times 2.5 \mathrm{~mm}$ in size, that were burnt to a whitish colour (one fragment being speckled grey and cream).

As for the probable function of this small vessel, clues are provided both by its diminutive size and by the fact that it has been thoroughly burnt, suggesting that it accompanied the body on the pyre. Similarly small vessels, which appear to have passed through the funeral pyre, are known from numerous Early Bronze Age graves containing cremated remains (Gibson 2004), and it has been suggested plausibly (Mortimer 1905) that they may have served as chafing vessels for transporting the burning embers used to light the pyre. A small vessel is all that would be required for such a task. An enigmatic ceramic object with Grooved Ware-style decoration found at Stonehenge, among cremated remains in one of the Aubrey Holes (Gardiner 1995, 360-1), may be another such chafing vessel, roughly contemporary with the Forteviot pot. A further, very similar vessel is known from Wareham House, Dorchester, Dorset (Parker Pearson 2012, 318).

The Forteviot pot does not, however, belong to the Grooved Ware ceramic tradition, which would have been in use in this part of Scotland at this time, for instance $4 \mathrm{~km}$ away at nearby Leadketty (Brophy 2016, 217-18). Stylistically, the closest comparanda for the Forteviot vessel are cups belonging to the Carinated Bowl tradition (Sheridan 2007), a tradition introduced to parts of Scotland early in the 4th millennium cal вс but which persisted, in 'modified' form (and alongside decorated ceramic styles), into the second half of that millennium. The occurrence of this vessel form in a Neolithic assemblage dominated by Impressed Ware pottery found at Meadowend Farm (Upper Forth Crossing), Clackmannanshire, shows that undecorated hemispherical cups were still in use towards the end of the 4th millennium (c. 3350-2900 cal BC: Jones et al. in press).

Nonetheless, the discovery of a Neolithic roundbased 'cup' in association with cremated human remains is unparalleled, and the radiocarbon dates associated with the Forteviot cemetery provide valuable information relating to the longevity of this vessel form, extending into the early $3 \mathrm{rd}$ millennium cal $\mathrm{BC}$.
CHRONOLOGY OF THE FORTEVIOT CREMATION CEMETERY AND COMPARANDA

Derek Hamilton

Seven radiocarbon dates are available from features associated with the cremation cemetery at Forteviot. The samples were all single entities (Ashmore 1999), of short-life material, either charcoal or cremated human bone. The samples were processed for radiocarbon dating at the Scottish Universities Environmental Research Centre, East Kilbride (SUERC) following the methods described by Dunbar et al. (2016). The graphite was then pressed into aluminium target holders for subsequent AMS analysis (Xu et al. 2004; Naysmith et al. 2010). The SUERC laboratory maintains rigorous internal quality assurance procedures, and participation in international intercomparisons (Scott 2003) indicates no laboratory offsets, thus validating the measurement precision quoted for the radiocarbon ages.

The radiocarbon results are given in Table 4. These are conventional radiocarbon ages (Stuiver \& Polach 1977), quoted according to the international standard set at the Trondheim Convention (Stuiver \& Kra 1986), and calibrated with the internationally agreed curve of Reimer et al. (2013) using OxCal v4.2 (Bronk Ramsey $1995 ; 1998 ; 2001 ; 2009)$. The date ranges in Table 4 have been calculated using the maximum intercept method (Stuiver \& Reimer 1986), and are quoted with the endpoints rounded outward to 10 years. The probability distributions seen in Figure 9 were obtained by the probability method (Stuiver $\&$ Reimer 1993).

The radiocarbon dates were subjected to Bayesian chronological modelling (Buck et al. 1991; 1996), which has been undertaken using the program $\mathrm{OxCal}$ v4.2 (http://c14.arch.ox.ac.uk/). Details of the algorithms employed by OxCal v4.2 are available in Bronk Ramsey $(1995 ; 1998 ; 2001 ; 2009)$ or from the online manual. The correlation between the OxCal model and data is gauged by the agreement indices, in particular the $\mathrm{A}_{\text {model, }}$ with values higher than 60 indicative of good agreement (Bronk Ramsey 1995). The results of the model are 'posterior density estimates', which are expressed as calendar years and presented in italics as probability ranges with end points rounded to the nearest 5 years. The algorithms used in the model can be derived from the $\mathrm{OxCal}$ keywords and bracket structure shown in the probability distribution plot. It should be emphasised that the posterior density estimates produced by modelling 
TABLE 4: RADIOCARBON DATES ASSOCIATED WITH THE FORTEVIOT CREMATION CEMETERY

\begin{tabular}{|c|c|c|c|c|c|}
\hline Lab no. & Material & Context & $\begin{array}{l}\text { Radiocarbon } \\
\text { age }(B P)\end{array}$ & $\delta^{13} \mathrm{C}(\%)$ & $\begin{array}{l}\text { Calibrated date } \\
(95 \% \text { confidence) }\end{array}$ \\
\hline $\begin{array}{l}\text { SUERC-29188 } \\
(\text { GU-21400) }\end{array}$ & $\begin{array}{l}\text { Cremated human bone: long bone } \\
\text { shaft frag. }\end{array}$ & 641 & $4370 \pm 30$ & -21.2 & $3090-2900 \mathrm{cal} \mathrm{BC}$ \\
\hline $\begin{array}{l}\text { SUERC-29185 } \\
\text { (GU-21397) }\end{array}$ & Charcoal: Alnus sp. & 641 & $4315 \pm 30$ & -26.4 & $3020-2890 \mathrm{cal} \mathrm{вС}$ \\
\hline $\begin{array}{l}\text { SUERC-29186 } \\
\text { (GU-21398) }\end{array}$ & $\begin{array}{l}\text { Cremated human bone: lower long } \\
\text { bone shaft frag. }\end{array}$ & 617 & $4275 \pm 30$ & -22.6 & $2920-2870 \mathrm{cal} \mathrm{вС}$ \\
\hline $\begin{array}{l}\text { SUERC-29184 } \\
(\text { GU-21396) }\end{array}$ & Charcoal: Alnus sp. & 628 & $4240 \pm 30$ & -26.7 & $2910-2760 \mathrm{cal} \mathrm{вС}$ \\
\hline $\begin{array}{l}\text { SUERC-29189 } \\
\text { (GU-21401) }\end{array}$ & Cremated human bone: femur frag. & 530 & $4180 \pm 30$ & -25.7 & $2890-2630 \mathrm{cal} \mathrm{вС}$ \\
\hline $\begin{array}{l}\text { SUERC-29187 } \\
\text { (GU-21399) }\end{array}$ & $\begin{array}{l}\text { Cremated human bone: upper long } \\
\text { bone shaft frag. }\end{array}$ & 628 & $4175 \pm 30$ & -22.0 & $2890-2630 \mathrm{cal} \mathrm{вС}$ \\
\hline SUERC-29180 & Charcoal: cf. Ulex/Cytisus sp. & 617 & $235 \pm 30$ & -24.5 & cal AD $1640-1950$ \\
\hline
\end{tabular}

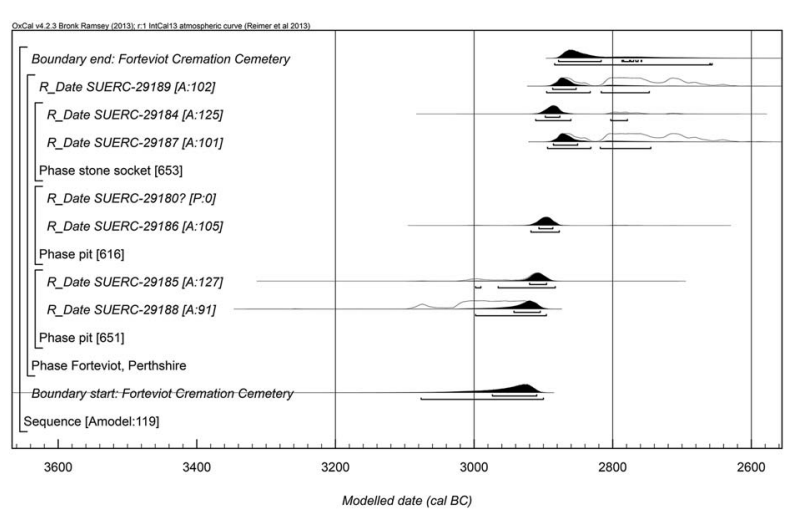

Fig. 9.

Chronological model for the dated cremation activity at Forteviot. Each distribution represents the relative probability that an event occurred at some particular time. For each of the radiocarbon measurements two distributions

have been plotted: one in outline, which is the result of simple radiocarbon calibration, and a solid one, which is based on the chronological model use. The other distributions correspond to aspects of the model. For example, 'start: Forteviot Cremation Cemetery' is the estimated date that this activity began, based on the radiocarbon dating results. The large square 'brackets' along with the OxCal keywords define the overall model

are not absolute, but rather they are interpretative estimates, which can and will change as further data become available and as other researchers choose to model the existing data from different perspectives.

Four of the nine cremation deposits excavated were radiocarbon dated (see Tables 4 \& 5). A sample of cremated bone (SUERC-29188) and alder charcoal
(SUERC-29185) were dated from small cremation pit [651] that contained four individuals. These two results are statistically consistent and could be the same actual age $\left(T^{\prime}=1.7 ; \mathrm{v}=1 ; \mathrm{T}^{\prime}(5 \%)=3.8\right)$. A fragment of gorse/broom charcoal (SUERC-29180) from cremation deposit (617) (SUERC-29180), is late post-medieval in date. This cremation deposit was in the area within the henge most disturbed by later activity, and this fragment of charcoal is likely to have been incorporated into the feature through later disturbance. It has been excluded from any further modelling. There are also two results on cremated human bone (SUERC-29187) and a fragment of alder charcoal (SUERC-29184) from the cremation deposit in context (566) lying near the stone socket [565]. The two results are statistically consistent $\left(T^{\prime}=2.3 ; \mathrm{v}=1\right.$; $\left.\mathrm{T}^{\prime}(5 \%)=3.8\right)$ and could be the same actual age. A final result (SUERC-29189) is available on cremated bone recovered from large pit [529].

After excluding SUERC-29180, the remaining radiocarbon results do not pass a $\chi^{2}$ test $\left(\mathrm{T}^{\prime}=32.7\right.$; $\left.\mathrm{v}=5 ; \mathrm{T}^{\prime}(5 \%)=11.1\right)$ suggesting that there is some longevity to the activity associated with the cremation cemetery. There is good agreement between the dates and the model that places them into an unordered group of activity $\left(A_{\text {model }}=119\right)$. The model estimates that the cremation cemetery began in 3080-2900 cal BC $(95 \%$ probability; Fig. 9; start: Forteviot Cremation Cemetery), and probably in 2975-2905 cal BC (68\% probability). This activity ended in 2885-2655 cal BC (95\% probability; Fig. 9; end: Forteviot Cremation Cemetery), and probably in either 2880-2815 cal BC 


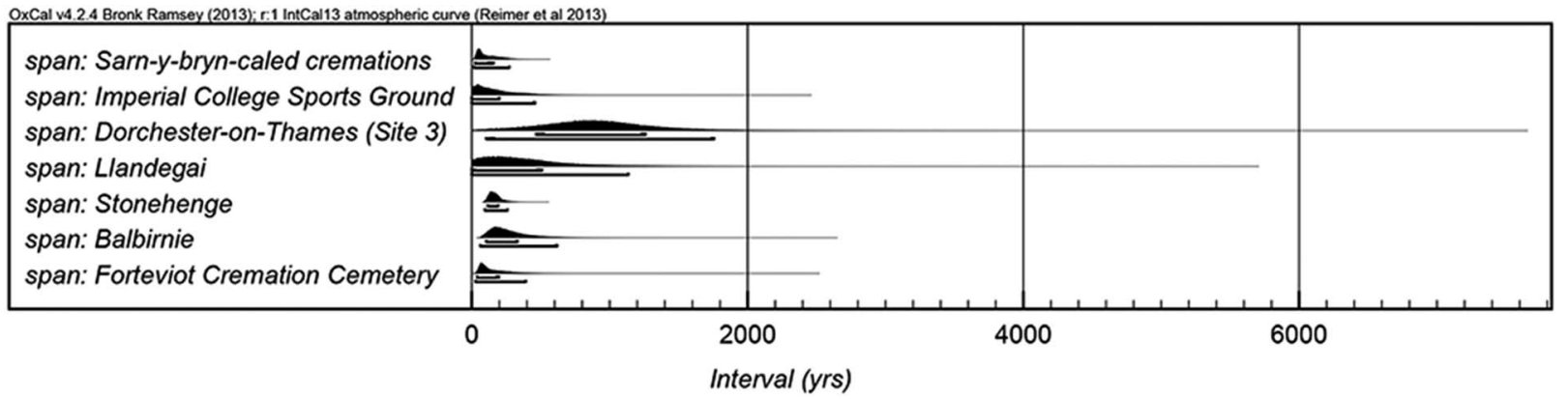

Fig. 10. Spans of overall dated activity for the sites modelled and shown in Figs 9 \& 11-16

(63\% probability) or $2790-2755$ cal BC $(5 \%$ probability). The dated activity spanned 25-395 years (95\% probability; Fig. 10), and probably 35-180 years $(68 \%$ probability).

The estimates for the start, end, and span of activity at the Forteviot cremation cemetery are less precise than we would hope. This is a result of the overall low number of radiocarbon dates that are included in the model not having the necessary amount of information to provide a more robust statistical analysis for the unordered group (Steier \& Rom 2000). While the results will be less precise, they are not necessarily less accurate, and often the $68 \%$ probability interval is the more probable estimate for the dated event.

As part of the modelling of the activity associated with the cremation activity at Forteviot, a re-evaluation was made of the radiocarbon dating evidence for Neolithic cremation cemeteries in Britain. In addition to Forteviot, this included: Balbirnie, Fife; Cairnpapple Hill, West Lothian; Stonehenge, Wiltshire; Imperial College Sports Ground, Middlesex; Llandygái, Gwynedd [English: Llandegai]; Sarn-y-bryn-caled, Powys; Flagstones, Dorset; and Dorchester-on-Thames Sites 2, 3, and XI, all Oxfordshire. With the exception of the very large number of radiocarbon dates from Stonehenge presented here $(n=33)$, Balbirnie, Forteviot, and Dorchester-on-Thames (Site 3) are the only others with a half dozen or more results (see Table 5). The low number of dates from many of the sites, including just a single date from three of them, does result in a disparity between sites in the precision of the results, and subsequently the level of detail possible with any inter-site comparisons.

Six radiocarbon dates on cremated human bone from Balbirnie stone circle have been modelled. These form a subset of the dated remains presented in
Gibson (2010a) that includes five 'foundation' deposits of cremated human bone (SUERC-24152, -24156, -24166, -24168 \& -24170) and a cremation deposit in stone-hole 9 (SUERC-24161) that was identified as secondary in its context. All of the cremations from Gibson's Phases 1 and 2 are included here in an unordered group to produce comparative start and end boundaries for the Neolithic-dated activity associated with the deposition of cremated remains. Two results (SUERC-24152 \& -24156) from Cremation III are statistically consistent $\left(\mathrm{T}^{\prime}=0.1\right.$; $\nu=1 ; T^{\prime}(5 \%)=3.8$; Ward \& Wilson 1978), and these have been combined prior to calibration to form mean Cremation III $(4364 \pm 23$ BP). The model has good agreement $\left(\mathrm{A}_{\text {model }}=104\right)$ and estimates that the Neolithic cremation activity began in 3240-2925 cal $B C$ (95\% probability; Fig. 11; start: Balbirnie), and probably in $3085-2955 \mathrm{cal}$ ВС $(68 \%$ probability). The activity ended in 2885-2565 cal BC (95\% probability; Fig. 11; end: Balbirnie), and probably in 2875-2755 cal BC (68\% probability). The total span of Neolithic cremation activity at Balbirnie was 60-620 years (95\% probability; Fig. 10; span: Balbirnie), and probably $100-330$ years $(68 \%$ probability). These results are comparable to those presented in Gibson (2010a).

There are four radiocarbon dates on deposits of cremated bone from Llandygái, north Wales that have been modelled together. The details of the samples and their archaeological context are reported in Lynch and Musson (2001; and see discussion, below). The dates all come from Henge A. Pit FA370 with cremated remains was located in the interior of Henge A. It contained the remains of an adult, and a sample of cremated bone produced GrA-22954 (4480 \pm 50 вР). Three of the five pits in a pit circle (Acc3, Acc $4 \&$ 
TABLE 5: MAIN SITES MENTIONED IN THE TEXT WITH A COMPARISON OF MONUMENT TYPES, NUMBER OF CREMATED DEPOSITS, GRAVE GOODS \& RADIOCARBON DATES

\begin{tabular}{|c|c|c|c|c|c|}
\hline Site & Monument type & Context of cremations & No. cremated deposits & Demography & Pyre evidence \\
\hline Balbirnie, Fife & Stone circle (10 stones) & $\begin{array}{l}\text { Beneath stones and set at base of stones. Radiocarbon } \\
\text { dating also shows secondary deposition of } \\
\text { cremated bone. All in eastern arc of circle }\end{array}$ & MNI 6 & Adults \& children & \\
\hline Cairnpapple Hill, West Lothian & $\begin{array}{l}\text { Stone setting (at least } 7 \text { stones), } \\
\text { irregular arc with possible central } \\
\text { 'cove' setting, surrounding stone } \\
\text { (or timber circle)? }\end{array}$ & $\begin{array}{l}\text { In or beside every stone hole except feature A. } \\
\text { Shallow scoops cut into tops of stone holes evident } \\
\text { in some sections. Further deposits seem to continue } \\
\text { arc of stone setting. Stones removed prior to Food } \\
\text { Vessel cairn. Stone setting open to W }\end{array}$ & 13 & Unknown & $\begin{array}{l}\text { Bones v. fragmented; token or v. } \\
\text { truncated deposits? }\end{array}$ \\
\hline $\begin{array}{l}\text { Dorchester-on-Thames Site I, } \\
\text { Oxfordshire }\end{array}$ & Double pit/timber circle/ring ditch & Found in or beside pits of inner circle & 4 & $\begin{array}{l}\text { Adults \& } 1 \text { adolescent; } \\
\text { inhumation in west part } \\
\text { of enclosure }\end{array}$ & \\
\hline $\begin{array}{l}\text { Dorchester-on-Thames Site II, } \\
\text { Oxfordshire }\end{array}$ & Multi-phase segmented ring ditch & $\begin{array}{l}16 \text { deposits spread within interior \& secondary silts } \\
\text { of ditches; } 5 \text { within centre in pits }\end{array}$ & 21 & $\begin{array}{l}\text { Adults \& children; pits with } \\
\text { multiple individuals }\end{array}$ & $\begin{array}{l}\text { Large to token/ } \\
\text { truncated deposits }\end{array}$ \\
\hline $\begin{array}{l}\text { Dorchester-on-Thames Site IV, } \\
\text { Oxfordshire }\end{array}$ & Timber circle ( $8 / 9$ posts) & $\begin{array}{l}25 \text { deposits: } 10 \text { directly above where posts removed, } \\
12 \text { within interior, \& } 3 \text { outside circle }\end{array}$ & 25 & Adults and adolescents & \\
\hline $\begin{array}{l}\text { Dorchester-on-Thames Site V, } \\
\text { Oxfordshire }\end{array}$ & Pit/timber circle (13/14 posts) & $\begin{array}{l}21 \text { deposits: } 12 \text { in central area, } 7 \text { in upper filling of } \\
\text { post-holes, \& } 2 \text { just outside lip of ditch. Dug in } \\
\text { shallow pits or just under topsoil }\end{array}$ & 21 & 1 deposit $=3$ individuals & $\begin{array}{l}\text { No grave goods \& free from } \\
\text { charcoal \& wood-ashes as at } \\
\text { other sites (?washed) }\end{array}$ \\
\hline $\begin{array}{l}\text { Dorchester-on-Thames Site VI, } \\
\text { Oxfordshire }\end{array}$ & Pit/timber circle (11/12 posts) & $\begin{array}{l}55 \text { deposits: } 13 \text { in central area, } 33 \text { in filling of } \\
\text { segments, } 3 \text { just outside ditch }\end{array}$ & 49 & $\begin{array}{l}\text { Adults } \& \text { adolescents. } 5 \\
\quad \text { deposits }=2 \text { individuals; } \\
1=3 \text { individuals }\end{array}$ & Petit tranchet arrowhead \\
\hline $\begin{array}{l}\text { Dorchester-on-Thames Site XI, } \\
\text { Oxfordshire }\end{array}$ & $\begin{array}{l}\text { Multi-phase ring ditch, innermost } \\
\text { ditch cut by pit/timber circle }\end{array}$ & $\begin{array}{l}\text { Cremated bone scattered throughout fill of pits } 6 \& \text { } \\
13 \text {. 'Whole' cremation cut into shallow pit next } \\
\text { to pit } 8\end{array}$ & 3 & & \\
\hline $\begin{array}{l}\text { Dorchester-on-Thames Site XIV, } \\
\text { Oxfordshire }\end{array}$ & $\begin{array}{l}\text { Ring ditch, surrounded square } \\
\text { four-post setting and pit }\end{array}$ & Cremated bone deposit in upper fill of ring ditch & 1 & & Group I Cornish axe \\
\hline $\begin{array}{l}\text { Dorchester-on-Thames Site 2, } \\
\text { Oxfordshire }\end{array}$ & Penannular ring ditch & $\begin{array}{l}\text { Cremations spread within interior \& secondary silts } \\
\text { of ring ditch }\end{array}$ & 28 & $\begin{array}{l}\text { Adults \& adolescents; pits } \\
\text { with multiple individuals }\end{array}$ & $\begin{array}{l}\text { Large to token/ } \\
\text { truncated deposits }\end{array}$ \\
\hline $\begin{array}{l}\text { Dorchester-on-Thames (Site 3), } \\
\text { Oxfordshire }\end{array}$ & $\begin{array}{l}\text { Pit/timber circle, charred timbers } \\
\text { found in situ }\end{array}$ & $\begin{array}{l}\text { All timber uprights burnt in situ? Cremated deposits } \\
\text { found in } 4 \text { of resulting hollows }\end{array}$ & 6 & Adults $\&$ adolescents & Includes cattle bone? \\
\hline Duggleby Howe, East Yorkshire & Large burial mound & 53 deposits from upper burial levels in mound & 53 & Adults $\&$ adolescents & \\
\hline Flagstones, Dorchester, Dorset & $\begin{array}{l}\text { Earthwork enclosure \& small } \\
\text { penannular enclosure within; } \\
\text { stone slabs from demolished } \\
\text { stone circle? }\end{array}$ & $\begin{array}{l}\text { In ditch base \& primary fill \& within pits inside } \\
\text { penannular enclosure. Covered by stone slabs }\end{array}$ & 7 & $\begin{array}{l}4 \text { infant burials in ditch fills } \\
\text { (undated) }\end{array}$ & \\
\hline Forteviot, Perthshire & Stone setting, irregular arc & In or beside stone holes/pit features & 18 & $\begin{array}{l}\text { Adults (male \& female) \& } \\
\text { children }\end{array}$ & $\begin{array}{l}\text { Very high pyre efficiency, high } \\
\text { collection rates }\end{array}$ \\
\hline $\begin{array}{l}\text { Imperial College Sports Ground, } \\
\text { Colne Valley, Middlesex }\end{array}$ & $\begin{array}{l}\text { Two ring ditches: one penannular, } \\
\text { one multi-ditched enclosure }\end{array}$ & $\begin{array}{l}\text { Adult female \& child in centre of } 1 \text { ring ditch; also } \\
\text { within enclosures \& ditch fills }\end{array}$ & 6 & Immature to adult & \\
\hline $\begin{array}{l}\text { Llandygái, Gwynedd, North } \\
\text { Wales }\end{array}$ & $\begin{array}{l}\text { Earthwork enclosure \& pit } \\
\text { enclosure with possible } \\
\text { standing stone at entrance }\end{array}$ & $\begin{array}{l}\text { Within enclosure } \& \text { pit circle. Those in pit circle } \\
\text { may have accumulated over time }\end{array}$ & $\begin{array}{l}1 \text { in main enclosure; } \\
\text { MNI } 6 \text { in pit circle }\end{array}$ & Newborn-adult & $\begin{array}{l}\text { Some token depositions or badly } \\
\text { truncated? }\end{array}$ \\
\hline Sarn-y-bryn-caled, Powys & Penannular ring ditch, $8 \times 7 \mathrm{~m}$ & Ditch terminal \& ditch fills & 4 & Adults \& children & \\
\hline Stonehenge, Wiltshire & $\begin{array}{l}\text { Earthwork enclosure, stone/timber } \\
\text { circle }\end{array}$ & $\begin{array}{l}\text { Associated with creation \& removal of stone circle } \\
\& \text { within ditch of earthwork enclosure. } \\
\text { Accumulating over lengthy period. Stones } \\
\text { removed }\end{array}$ & $27+$ & $\begin{array}{l}\text { Adults, particularly males } \\
\text { dominant; small number } \\
\text { child burials }\end{array}$ & $\begin{array}{l}\text { Burial C42: high collection of } \\
\quad \text { bones \& well-cremated remains }\end{array}$ \\
\hline West Stow, East Anglia & $\begin{array}{l}\text { Ring ditch, possible covering } \\
\text { barrow }\end{array}$ & $\begin{array}{l}49 \text { deposits: } 1 \text { inserted into fill of primary } \\
\text { inhumation burial pit, } 46 \text { others within ditch \& } \\
\text { inner lip, } 2 \text { around } 3 \mathrm{~m} \text { from outer edge of ditch }\end{array}$ & 49 & $\begin{array}{l}\text { Immature to adult, male \& } \\
\text { female. At least } 8 \text { deposits } \\
\text { of multiple individuals }\end{array}$ & Efficient pyre process \\
\hline
\end{tabular}


TABLE 5: CONTINUED

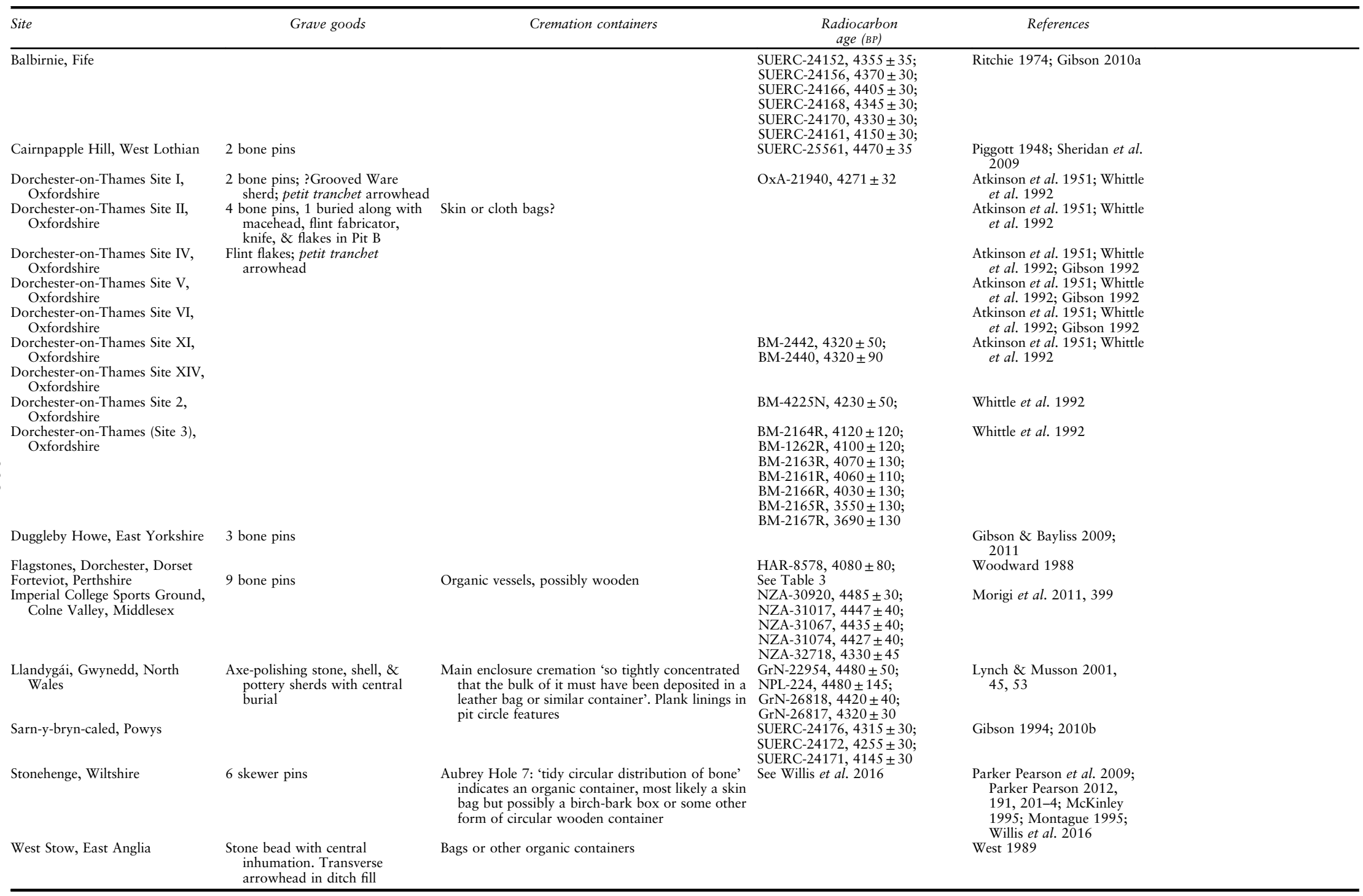




\section{G. Noble \& K. Brophy. NEOLITHIC CREMATION CEMETERY, FORTEVIOT, PERTH \& KINROSS}

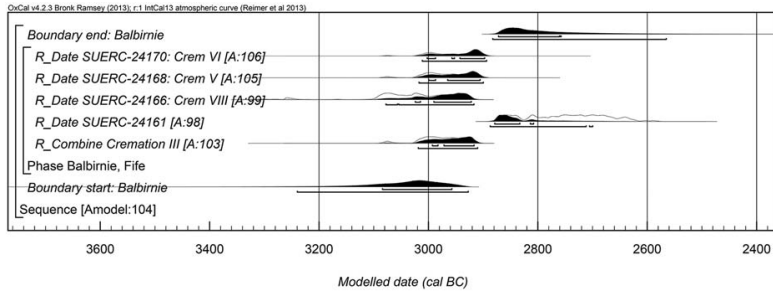

Fig. 11.

Chronological model for Balbirnie. The model structure is as described in Fig. 9

Acc2) had charcoal samples dated (NPL-224 \& GrN-26817/-26818). Pit Acc2 contained the remains of an adult and an infant with the sample (A118) dated from oak fragments from a possible log or plank, along with fragments of holly or rowan type. Pit Acc3 contained bones that belonged mostly to an adult/subadult along with two immature bones; the sample (A112) also consisted mainly of oak from a possible plank at the bottom of the pit. Acc 4 contained what was interpreted as a token burial of a fragment of skull and upper limb from an adult/subadult, with the sample (A79) entirely of oak. There are no stratigraphic relationships between the features or samples, and so they are modelled simply as being directly related to activity associated with the deposition of cremated remains at Henge A. The model has good agreement $\left(\mathrm{A}_{\text {model }}=87\right)$ and estimates that the deposition of cremated remains at Llandygái, Henge A began in 3745-2930 cal $B C$ (95\% probability; Fig. 12; start: Llandegai), and probably in 3360-3020 cal BC (68\% probability). This activity took place for $1-1160$ years (95\% probability; Fig. 10; span: Llandegai), and probably for $1-490$ years $(68 \%$ probability). The cremation activity ended in 3080-2455 cal BC $(95 \%$ probability; Fig. 12; end: Llandegai), and probably in $3005-2820$ cal $B C(68 \%$ probability). While the low number of dates will result in estimates with relatively low precision, the four radiocarbon measurements presented here do not pass a $\chi^{2}$ test $\left(T^{\prime}=9.5 ; \nu=3\right.$; $\left.\mathrm{T}^{\prime}(5 \%)=7.8\right)$, which indicates some longevity to the activity. The dating of oak charcoal, with a potential unknown age offset, in three samples could be one explanation for this longevity. However, the radiocarbon measurement (GrN-26817) from Acc4, which is entirely of oak, is the youngest measurement, and the one that is not in agreement with the remaining three. That a large amount of oak charcoal has been used in the dating should raise some caution in the overall interpretation of these results, as the entire set,

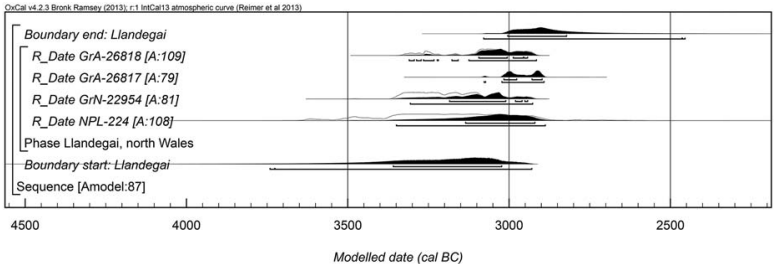

Fig. 12.

Chronological model for Llandygái. The model structure is as described in Fig. 9

including the result on cremated bone, could potentially suffer an offset. However, given the low precision of the posterior date estimates, this does not affect the overall model.

Three dates are available from cremation deposits from another Welsh site, a small penannular ring ditch at Sarn-y-bryn-caled. Gibson (2010b) obtained dates directly from cremation deposits found in the ditch fills of the enclosure. The dates were from three of four cremation deposits. These were overlain by two deposits that were dated from oak charcoal, which Gibson (2010b) excluded from consideration as residual material. The model is simplified here to exclude the residual charcoal that does not provide chronological control for the underlying cremations, but also to update the results for the cremations by using the IntCal13 calibration curve. In the original publication, the deposition of the dated cremations 1-3 were placed in a stratigraphic order, while cremation 4 (undated) was unable to be stratigraphically linked. The cremations are similarly ordered here. The model has good agreement $\left(A_{\text {model }}=121\right)$ between the radiocarbon dates and the stratigraphic order of the samples. If we assume that cremation 4 lies somewhere between the first and last of the securely stratified cremations, we can use their posterior probabilities to estimate the date of the cremation activity at Sarn-ybryn-caled. Cremation 1 provides an estimated start date for the rite in either 3010-2985 cal $B C \quad(4 \%$ probability; Fig. 13; SUERC-24176: cremation 1) or 2970-2885 cal $B C$ (91\% probability), and probably in 2925-2895 cal $B C(68 \%$ probability). The last cremation in this series (cremation 3) dates to 2890-2675 cal BC $(95 \%$ probability; Fig. 13; SUERC-24171: cremation 3), and probably either to $2880-2830 \mathrm{cal} B C$ (61\% probability) or $2725-2800$ cal BC $(7 \%$ probability). By subtracting the posterior probability for the earliest cremation from the latest, it is possible to derive an overall time span for cremation activity. 


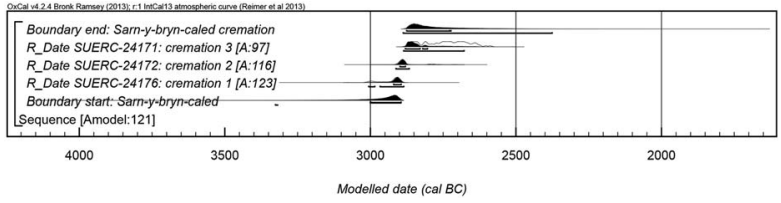

Fig. 13.

Chronological model for Sarn-y-bryn-caled. The model structure is as described in Fig. 9

The overall span of the dated cremations is $10-260$ years (95\% probability; Fig. 10; span: Sarn-y-bryncaled), and probably $15-120$ years (68\% probability).

Stonehenge has been the focus of a number of programmes of radiocarbon dating and Bayesian chronological modelling over the years (Cleal et al. 1995; Parker Pearson et al. 2007; Darvill et al. 2012). The most recent research utilised 37 radiocarbon dates from 29 samples of cremated human bone, dated and modelled from the cremated deposits in Aubrey Hole 7 and an adjacent cremation deposit, along with deposits within Aubrey Hole 32 and cremation deposits in ditch context 3898 (Willis et al. 2016). There was one result $(\mathrm{OxA}-17958 ; 3961 \pm 29 \mathrm{BP})$ on a cremated fragment of a young/mature adult radius from ditch context 3893 significantly later than the dated Neolithic cremations that calibrates to the Chalcolithic (2570-2360 cal BC; 95\% probability), and it has not been included in the modelling. There are no stratigraphic relationships between these samples, and so they are modelled as an unordered group. Although Willis et al. (2016) opted to impose a trapezium prior distribution on the dataset (Lee \& Bronk Ramsey 2012), the data are modelled here using the 'standard' uniform prior distribution. The primary difference between the two approaches is that the trapezium prior allows for cremation activity to have gradually grown in magnitude before settling into a period of relatively uniform activity, and then a gradual decline. The 'standard' uniform prior on the other hand assumes a more consistent use of the cemetery that proceeds from no activity to continuous and then to no activity once again. The model for the Stonehenge cremation deposits has good agreement $\left(\mathrm{A}_{\text {model }}=89\right)$ and estimates the cremation activity began in 3060-2945 cal BC (95\% probability; Fig. 14; start: Stonehenge) and probably in 3030-2965 cal BC (68\% probability). This activity ended in 2865-2780 cal $B$ С $(95 \%$ probability; Fig. 14; end: Stonehenge) and probably in 2860-2830 cal BC (68\% probability). The overall span of dated cremation activity was
95-250 years (95\% probability; Fig. 10; span: Stonehenge), and probably $120-195$ years $(68 \%$ probability). While the approach of Willis et al. (2016) is perfectly valid, the modelling choice used here produces estimates that are slightly more precise and allow us to compare the cremation activity from across these sites using the same prior distribution.

Seven dates are available from material associated with four deposits of cremated remains from Dorchester-on-Thames (Site 3). Three dates (BM-2163R, -2165R \& -2166R) are from charcoal samples recovered from post-pipes of F2009, F2013, and F2014, which form part of the post-circle. Deposits of cremated human bone were found at the top of these postholes, which were dated with samples of the outer rings of mature oak charcoal (BM-2161R, $-2162 R \&-2164 R)$. The dates from these three features have been modelled as three sequences, in addition to a result (BM-2167R) on unidentified material associated with an additional cremation deposit. As the dates from the postholes are on charcoal samples, and specifically from the outer rings of mature oak, it seems unlikely that the material dated is directly related to the cremation activity. Therefore, the modelling takes a conservative approach for producing a date for the activity associated with the timber circle, within which the cremated material was recovered. The model has good agreement $\left(A_{\text {model }}=90\right)$ and estimates that activity associated with the timber circle and deposition of cremated remains began in 33352500 cal $B C \quad(95 \%$ probability; Fig. 15 ; start: Dorchester-on-Thames (Site 3)), and probably in 3000-2635 cal $B C(68 \%$ probability). The activity lasted for 100-1785 years (95\% probability; Fig. 10; Dorchester-on-Thames (Site 3)), and probably for 490-1260 years $(68 \%$ probability). The activity ceased in 2460-1395 cal BC (95\% probability; Fig. 15; end: Dorchester-on-Thames (Site 3)), and probably in 2250-1720 cal BC $(68 \%$ probability). From Dorchester-on-Thames Site 2 there is a single radiocarbon result (BM-4225N; $4230 \pm 50 \mathrm{BP})$ on a red deer antler with beam and brow tine from the primary fill of the penannular ditch. The upper fill of the ditch was cut by a number of deposits of cremated remains, for which the date $2920-2670$ cal BC (95\% probability) provides a terminus post quem. At Site XI of Dorchesteron-Thames there are two results (BM-2440 \& -2442) on antler picks recovered from various, but unknown, levels in the fills of Ditch 1. The fills of two pits, 8 and 13, contained cremated human bone, and pit 13 directly cut 
G. Noble \& K. Brophy. NEOLITHIC CREMATION CEMETERY, FORTEVIOT, PERTH \& KINROSS

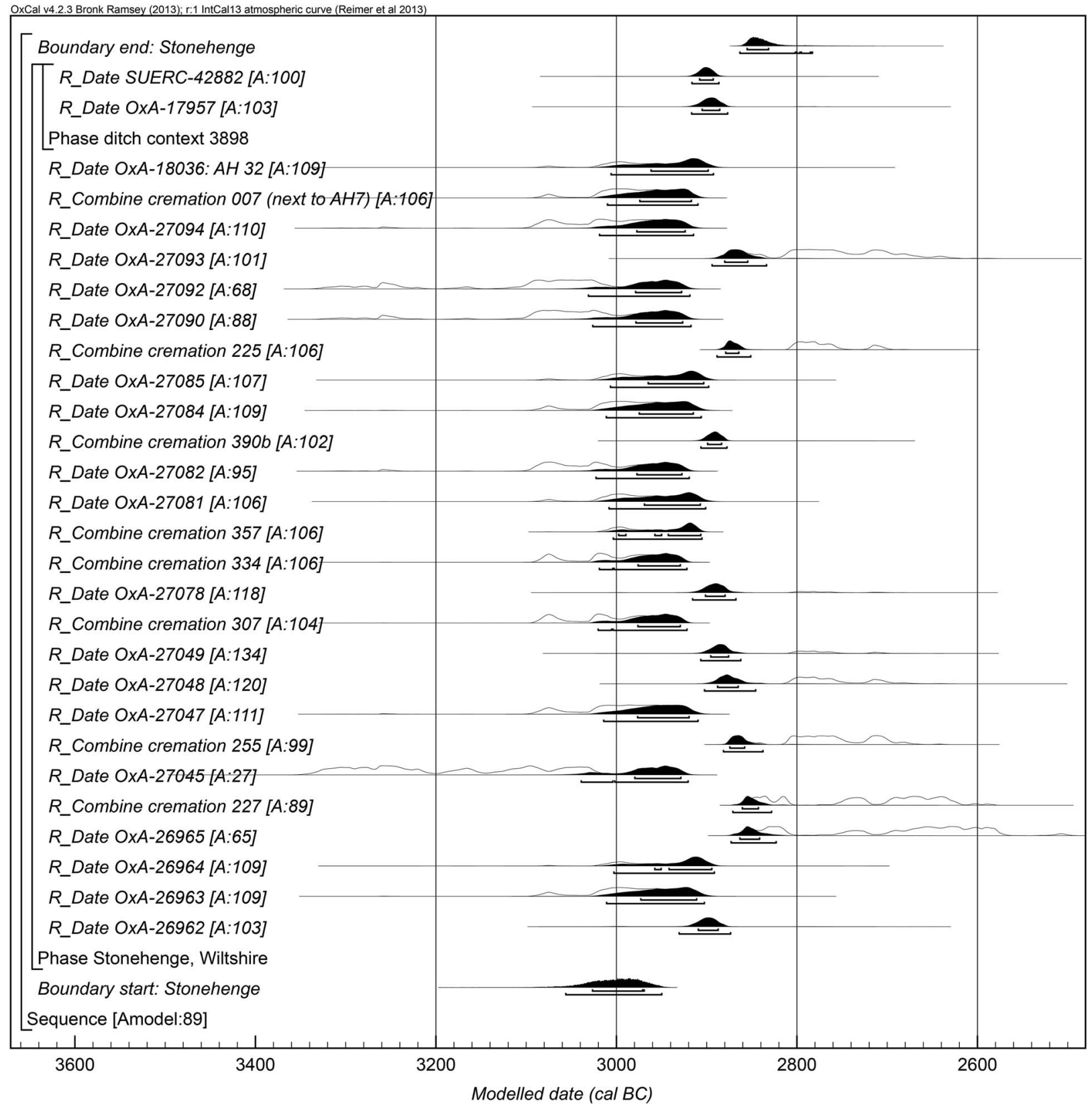

Fig. 14.

Chronological model for Stonehenge. The model structure is as described in Fig. 9

Ditch 1. The later result (BM-2442) provides a terminus post quem of $3090-2880 \mathrm{cal}$ вС (95\% probability) for the cremation activity associated with the pits.

Two ring ditch monuments from the Middle Thames Valley at the Imperial College Sports Ground (ICSG) have recently been dated. One sample (NZA-30920) comes from a central cremation deposit within a double-ditched ring ditch, and two samples (NZA-31067 \& NZA-32718) came from two further cremation deposits within the monument interior. A sample from a deposit of possible pyre debris in a fill of the outer ring ditch produced a further date from charred plant material (NZA-31074), and a single date (NZA-31017) was obtained from a cremation 


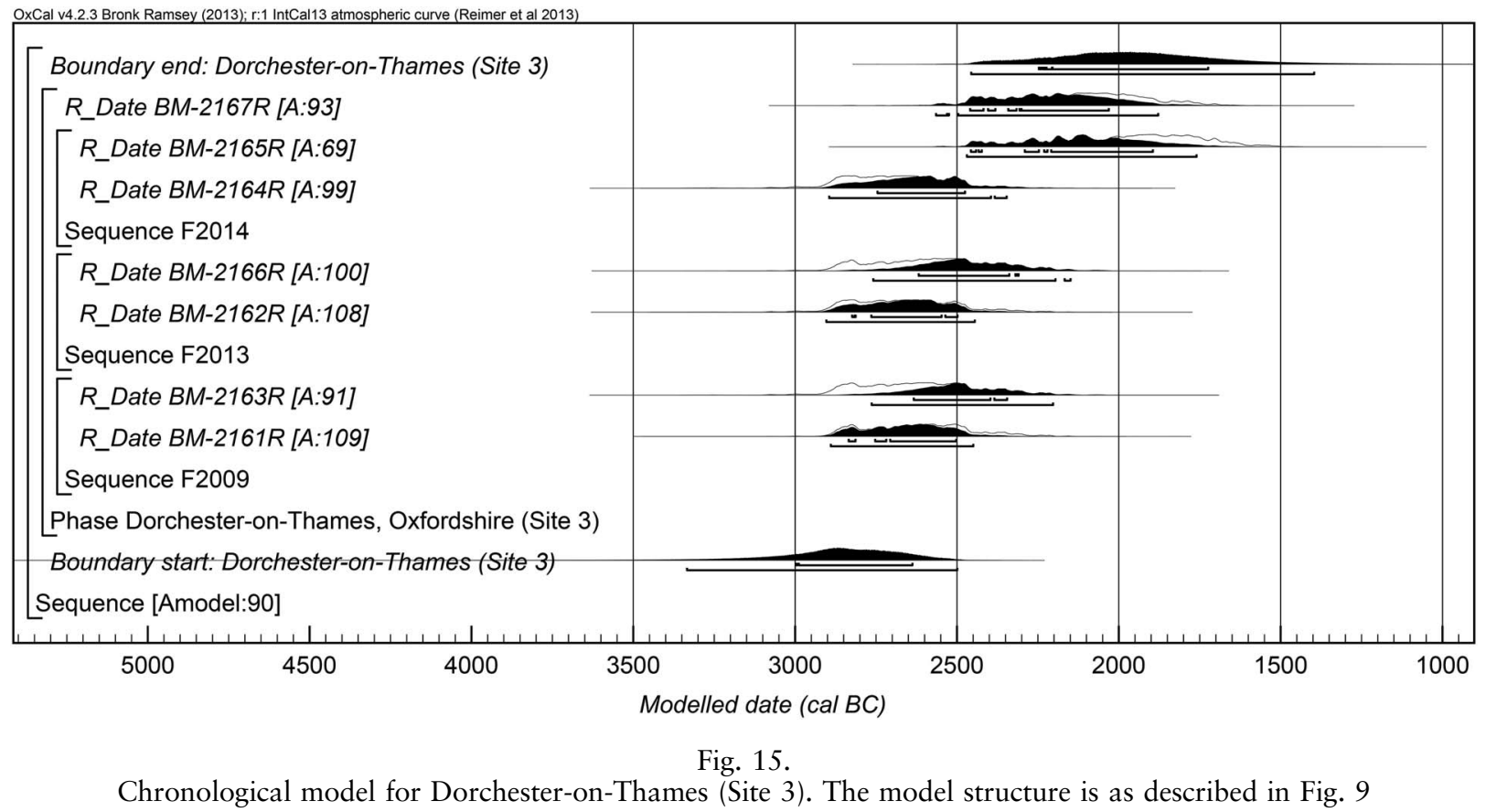

deposit from an adjacent ring ditch (Powell et al. 2015, 27-8; table 11.1). Two dates (NZA-30919 \& -31018) are from two cremation deposits associated with a penannular ditch (G2002), while a final result (NZA-32693) is from a discrete cremation. The model presented in Powell et al. (2015, 298, fig. 11.1) was updated to use the latest radiocarbon calibration curve (IntCal13). This model has good agreement $\left(\mathrm{A}_{\text {model }}=\right.$ 88 ) and estimates that cremation activity at ICSG began in 3345-3030 cal BC (95\% probability; Fig. 16; start: Imperial College Sports Ground), and probably in $3150-3040$ cal BC $(68 \%$ probability). The modelling provides an estimated end date for this burial rite at ICSG in 3090-2845 cal BC $(95 \%$ probability; Fig. 16; end: Imperial College Sports Ground), and probably in 3060-2925 cal BC (68\% probability). The rite here lasted for 1-450 years (95\% probability), and probably for 1-200 years (68\% probability).

Finally, a few other dates are worthy of consideration. SUERC-25561 ( $4470 \pm 35 \mathrm{BP})$ is from a sample of burnt bone or antler pin (NMS X.EP 162) from a deposit of cremated human remains in hole $\mathrm{C}$, one of an arc of pits at Cairnpapple Hill, the closest contemporary cemetery to that at Forteviot. The result calibrates to 3350-3020 cal BC (95\% probability). HAR-8578 $(4030 \pm 100 \mathrm{BP})$ is from a red deer antler recovered at the base of a ditch section from the Flagstones enclosure, Dorset. Also at the

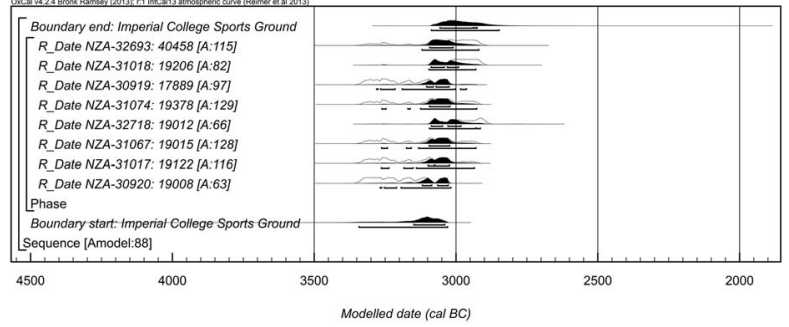

Fig. 16.

Chronological model for Imperial College Sports Ground. The model structure is as described in Fig. 9

base of the ditch were recovered the cremated remains of an adult and the inhumations of two children, each beneath a slab of sandstone or sarsen. The radiocarbon result provides an estimate for when the ditch was open and these burials could have been placed in 2890-2460 cal вс (95\% probability).

The probabilities for the start and end dates of all the modelled sites and the individual calibrated dates for the remaining sites are presented together in Figure 17.

\section{DISCUSSION: CREMATION CEMETERIES IN BRITAIN}

The first major phase of activity pre-dating the Chalcolithic Forteviot Henge 1 was the creation of a place that 


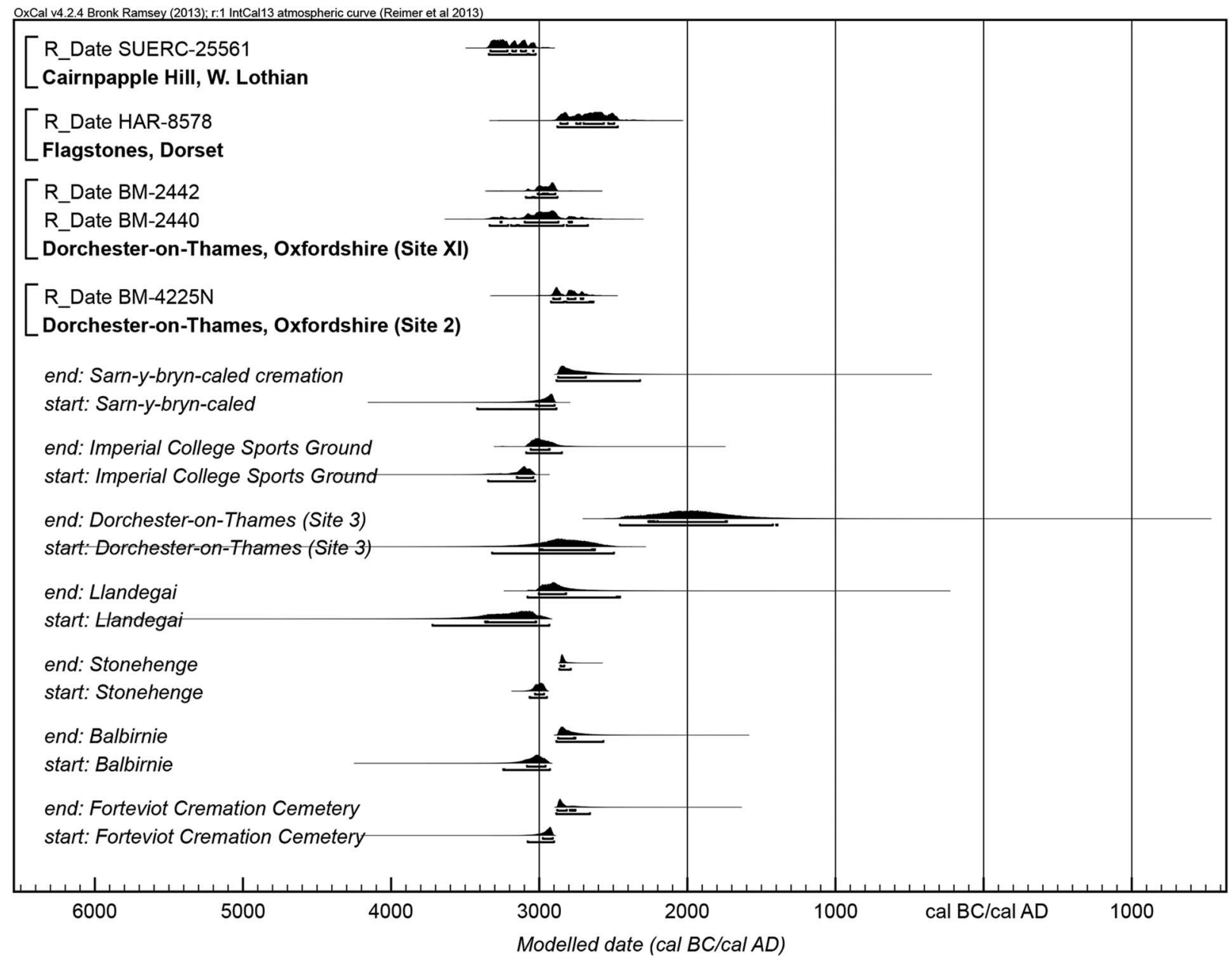

Fig. 17.

Probabilities for the start and end dates of all modelled sites, along with those cremation sites discussed in the text with less than three radiocarbon dates

became the focus for the deposition of cremated human remains; perhaps it was the catalyst for the establishment of a ceremonial complex in this landscape. Forteviot represents the largest assemblage of late 4th/early 3rd millennium cal $\mathrm{BC}$ cremated human remains discovered to date in Scotland. The results of the work here have added to a growing corpus of mortuary sites of similar date, which have great potential to add to current thinking on Neolithic mortuary practice and cremation rites in Britain and beyond (eg, Parker Pearson et al. 2009; Cooney 2016), thus helping address a longestablished lacuna in our understanding of this period in Britain (cf. Barclay 2003, 132-3; Healy 2012).

More than a dozen cremation cemeteries of this date have now been identified in Britain (Parker
Pearson et al. 2009, 34-5; Willis et al. 2016, 352-3; and see Table 5; Fig. 18). We will begin our discussion by looking at two comparable sites to Forteviot in Scotland before moving onto a broader geographical focus. The reader is referred to Hamilton's discussion, above, for detailed chronological discussion of many of these sites and associated modelling.

\section{Late 4thlearly 3rd millennium cal BC cremation cemeteries in Scotland}

The closest regional parallel for the Forteviot cemetery is Cairnpapple Hill, c. $45 \mathrm{~km}$ to the south (Piggott 1948; Barclay 1999). There, Piggott identified a prehenge phase focused on an arc-shaped 'stone setting' 


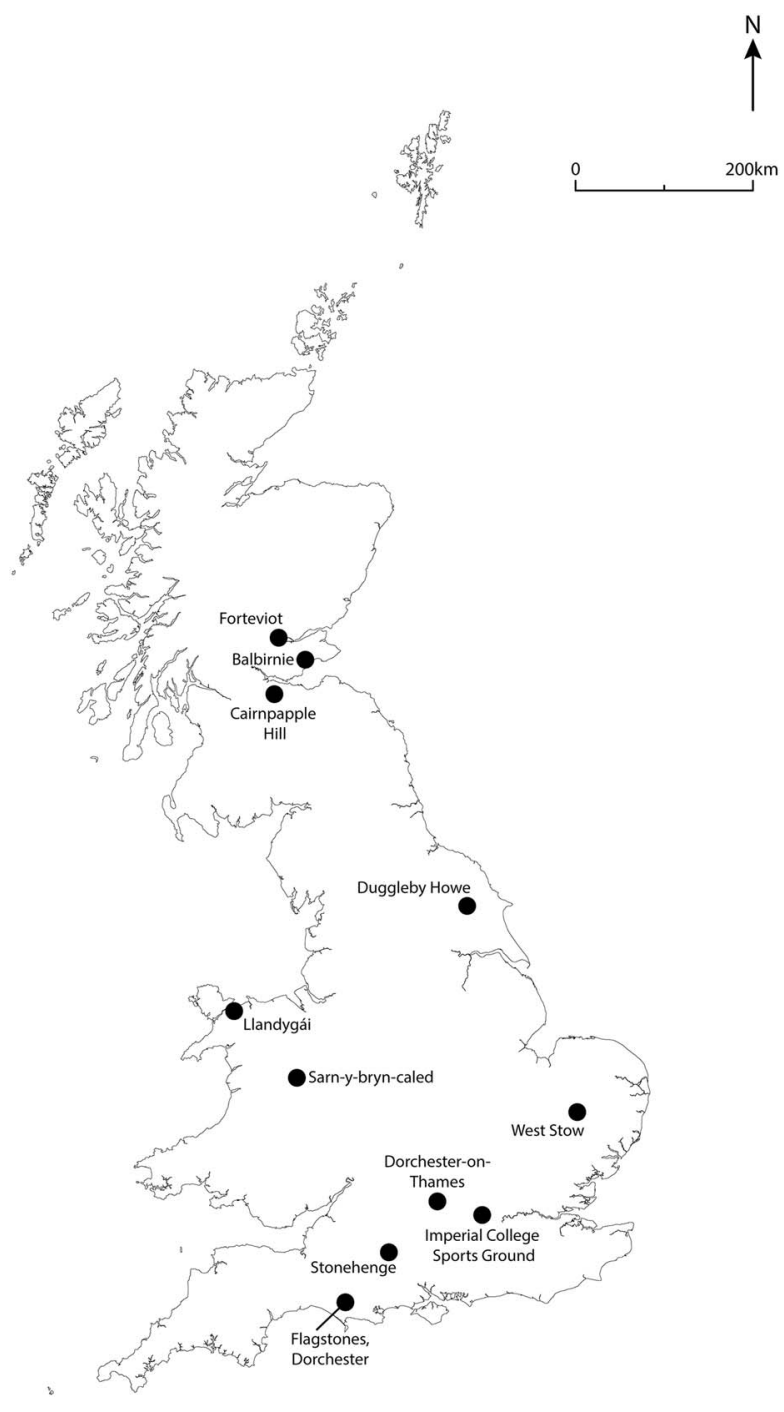

Fig. 18.

Distribution map of the major Neolithic cremation cemeteries in Britain

(Fig. 19), indicated by seven cut features which he argued were standing stone sockets (holes A-G; Piggott 1948, 76). Most contained packing stones, some perhaps freshly broken fragments of larger stones. For all but one stonehole, deposits of cremated human bone were found in fills or shallow scoops cut into the sides of the features. The burials were in a more truncated state than those at Forteviot and only very small fragments and low overall weights of bone were recovered. In no instance was an intact deposit identified. Eight cremation deposits were identified with a further five found in positions that appear to

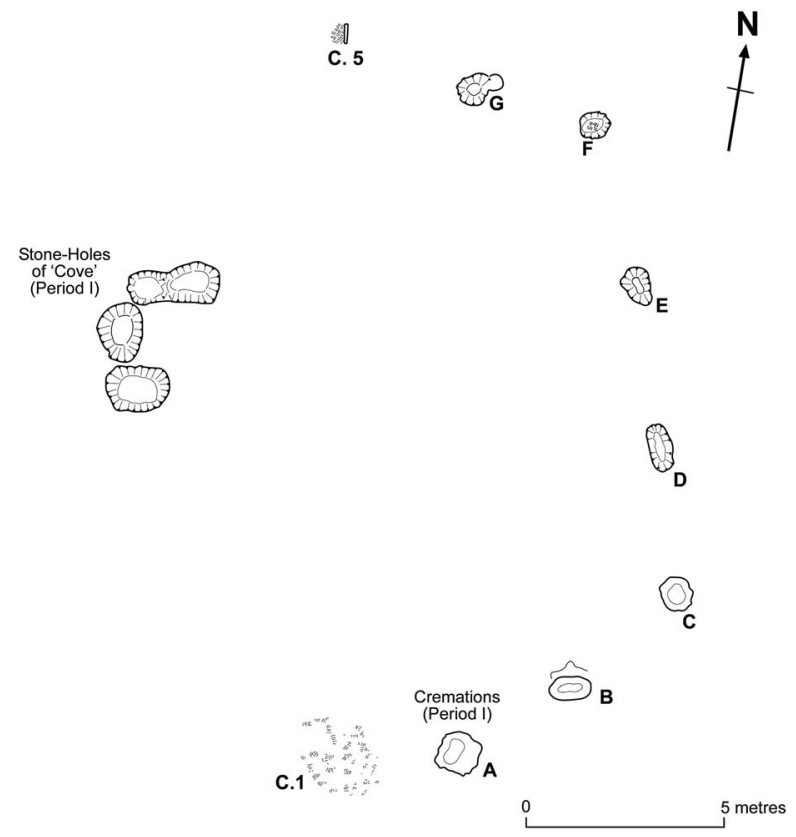

Fig. 19.

Plan showing the locations of the cremated human bone found at Cairnapple Hill (after Piggott 1948 \& Barclay 1999; drawn by Alison Sandison)

continue the arc of the 'stone setting'. Two bone pin fragments of the same type as the Forteviot pins were found in association with deposits of cremated bone. Piggott was not able to draw on radiocarbon dating, but he compared the Cairnpapple bone pins to Neolithic examples from Stonehenge, Dorchester-onThames, and Duggleby Howe (ibid., 101). Recent dating of a fragment of one Cairnpapple pin by the National Museums of Scotland to 3350-3020 cal вс (SUERC-25561; $4470 \pm 35 \mathrm{BP}, 95 \%$ probability; Sheridan et al. 2009) confirms Piggott's attribution of the cemetery to the Neolithic and more specifically to the late 4th/early 3rd millennium cal BC.

A further cremation cemetery has only recently been identified as Neolithic in date and contemporary with Forteviot, thanks to a series of new dates procured by Gibson (2010a) on material from Balbirnie stone circle (Ritchie 1974). Balbirnie consisted of a circle, c. $15 \mathrm{~m}$ in diameter, of ten stones with a central rectangular stone setting. Despite truncation, a series of mostly single cremation deposits of adults and children were recovered during Ritchie's excavations in the early 1970s, most from standing stone sockets. Balbirnie is part of a much larger complex of monuments which included henge monuments and timber settings at 


\section{G. Noble \& K. Brophy. NEOLITHIC CREMATION CEMETERY, FORTEVIOT, PERTH \& KINROSS}

Balfarg (Barclay \& Russell-White 1993). As noted above, Hamilton's Bayesian modelling (Figs 10 \& 11) shows that the cemetery probably began in 30852955 cal $B C(68 \%$ probability) and ended in 2875 $2755 \mathrm{cal} B C(68 \%$ probability), which is broadly similar to the Forteviot dates (start date 2975-2905 cal $B C ; 68 \%$ probability and end date either 2880 2815 cal $B C ; 63 \%$ probability or $2790-2755$ cal $B C$; 5\% probability; see also Gibson 2010a, 63, illus. 2).

\section{Late 4thlearly $3 r d$ millennium cal BC cremation cemeteries beyond Scotland}

Further important parallels for Forteviot lay outwith Scotland and will be briefly discussed here (see also Parker Pearson et al. 2009; Gibson 2016). The bestknown cemetery identified to date is at Stonehenge, where the earliest phase has recently been argued to be a cremation cemetery affiliated with a stone circle in association with the so-called Aubrey Holes (Parker Pearson et al. 2009; Parker Pearson 2012; Willis et al. 2016; see also Hawley 1921, 30-1). Re-analysis of cremations found by Hawley in the 1920s, as part of the Stonehenge Riverside Project, identified a minimum number of 27 individuals, the majority adults, but estimates of the total number of deposits of cremated bone have ranged from 150 to 240 individuals (Parker Pearson et al. 2009; Parker Pearson 2012, 203; Willis et al. 2016). Some of the Stonehenge cremations were accompanied by bone pins and other notable finds, including a mace-head and a small pottery vessel (Cleal et al. 1995, 360-1; Montague \& Gardiner 1995, 394). The modelled dates for the start of the Stonehenge cremation cemetery presented by Hamilton above (Figs $10 \& 14$ ), are broadly similar to Forteviot - the start dates at Stonehenge fall in the range 3030-2965 cal $B$ С (68\% probability) compared to 2975-2905 cal BC (68\% probability) at Forteviot. Willis et al. $(2016,349)$ estimate a slightly earlier start date (3075-2985 cal BC) for the Stonehenge cemetery.

Although Stonehenge has been claimed as the largest cemetery of the late 4th/early 3rd millennium cal BC in Britain (Willis et al. 2016, 353), this is based on an un-tested extrapolation; the largest number of confirmed Middle-Late Neolithic cremation deposits recovered in Britain is actually from Dorchester-onThames, the biggest Neolithic monument complex known to date in the Thames Valley (Atkinson et al. 1951; Kinnes 1979; Whittle et al. 1992). At Dorchester, a series of monuments associated with the deposition of cremated remains was constructed in the centuries around $3000 \mathrm{cal} \mathrm{BC}$, including multi-phase ring ditches (Site XI), probable timber circles (Sites 3, $\mathrm{IV}, \mathrm{V} \& \mathrm{VI}$ ), a penannular ring ditch (Site 2), and sites that combined elements of all three enclosure types (Sites I, II \& XIV) (see Table 5). Bone pins of similar character to those from Forteviot were found at Sites I and II. Previous dating of the monument complex at Dorchester-on-Thames has shown that these monuments broadly date to the first half of the 3rd millennium cal BC (Garwood \& Barclay 2011, 401). Hamilton's modelling (above) has shown that deposition of cremated remains at Site 3 began sometime in the period 3000-2635 cal BC $168 \%$ probability) and that some of the activity at Site 2 and Site XI began after 2920-2670 cal BC and 3090-2880 cal $B C$ respectively (both $95 \%$ probability). The dating, however, is largely unsatisfactory for this important series of sites.

Two new sites have recently been identified in the Middle Thames Valley at the Imperial College Sports Ground, albeit with more modest numbers of cremation deposits (Powell et al. 2015, 25-32). The largest monument consisted of a double ring ditch with a central grave that contained an unurned cremation deposit comprising the remains of a possible adult female and a young child. Two other unurned cremation deposits lay within the ring ditch, and a further cremation deposit was dug in a shallow feature cut into the inner ditch's upper fill. Immediately north, a small penannular ring ditch contained two further unurned cremation graves. The Imperial College Sports Ground sites are amongst the earliest considered here with Bayesian modelling suggesting a 3150-3040 cal BC (68\% probability) start date. Other possible parallels to the Forteviot cemetery in the south of England include the large enclosures at Flagstones, Dorchester and West Stow, Suffolk (Table 5).

In northern England, the best-known cremation cemetery is Duggleby Howe in North Yorkshire, where a large mound contained evidence for a sequence of well over 500 years of burial activity, with at least 53 cremation deposits made here before the mound was capped (Gibson \& Bayliss 2009; Gibson et al. 2011; and see Mortimer 1905). Although these have been lost since being excavated, the typology of the associated artefacts suggests broad contemporaneity with Forteviot and Stonehenge (Gibson \& Bayliss 2009; Gibson 2016, 67). (Duggleby Howe formed an important part of Piggott's definition of the 'Dorchester Culture'.) 
Cremation cemeteries also occurred in the west. Llandygái, in north Wales, perhaps commenced with the burial of a single individual in a pit within a henge monument, opposite the entrance and beneath the internal bank (Lynch \& Musson 2001). The deposition of the cremated remains of this adult female, accompanied by an axe-polishing stone, has a start date of $3360-3010$ cal BC $(68 \%$ probability). A modest pit circle, $9 \mathrm{~m}$ in diameter and defined by five banana-shaped pits, was constructed outside the henge, possibly at a later date (terminus post quem 3020-2890 cal BC, 95\% confidence; GrA-26817, $4320 \pm 30$ вр). The fills of these pits were suggestive of having held timber planking. The fills also included charcoal and burnt bone, and one pit contained a large damaged stone, suggesting that some pits may have once held standing stones or stone markers (ibid., 48). The cremated remains were fragmentary, but included at least six individuals of newborn to adult age. As with many of the other sites noted in this discussion, Henge A at Llandygái was only one component of an emergent and developing monument complex. The other known Welsh site is the much more modest penannular ring ditch at Sarn-y-bryn-caled in Powys (Gibson 2010b, 34-55; Table 5). Modelling suggests the cremations here began to be deposited in the period 2925-2895 cal BC (68\% probability).

Place-making in the late 4thlearly 3rd millennium cal $B C$ The sites described above (see Table 5; Fig. 18) demonstrate that in the centuries around $3000 \mathrm{cal} \mathrm{BC}$, a range of circular enclosures across Britain became the focus for the deposition of cremated human remains. There was variability underlying the form of these monuments, with enclosures of widely different sizes and material forms evident, and the number of individuals buried, ranging from small groups to well over 100 (Table 5). Nonetheless, what is becoming clear is that, regardless of this variation, these cemeteries and accompanying monuments represent a significant tradition that can be related to broader changes that were occurring in Neolithic society at the time of their creation.

Chronologically, sites such as Llandygái and Cairnpapple appear earlier than Forteviot, but the dating for these sites relies on small numbers of dates and/or mixed/oak sources. A small plateau or wiggle in the calibration curve at the end of the 4th millennium cal BC may also further accentuate perceived differences when viewing calibrated dates only. The dates from the relatively modest monuments and small numbers of cremations at Imperial College Sports Ground are more reliable and suggest a start date in the late 32 nd or 31 st century cal BC. The dates from Balbirnie, Forteviot, and Stonehenge would suggest broadly contemporary establishment for these larger cemeteries in the 31st or 30th century cal BC (Fig. 17).

The traditions of mortuary practice that existed prior to the establishment of these cremation cemeteries in lowland Britain is not entirely clear. Occasional inhumation and cremation burials occur through the Middle to Late Neolithic, but they are relatively few in number and cemeteries are scarce, with chronologies not always fully resolved (eg, Healy 2012, 150-1). In England, for example, there are burials within oval or round barrows with furnished inhumations that could form a pre-cursor to the cremation cemeteries, but their chronologies are frustratingly vague (eg, Morigi et al. 2011). Cremation traditions may also have built on earlier inhumation practice; there is a general recognition that cremation and inhumation burials did occur in close proximity and temporality to one another in Britain and Ireland (cf. Cooney 2016; Gibson 2016). However, evidence of direct continuity is rare, with the exception perhaps of Duggleby Howe where inhumations began as early as the 36th century cal $\mathrm{BC}$ and then occurred again in the late 31 st or early 30th century cal BC (3015-2985 cal $B C, 95 \%$ probability; GrA-33102; Gibson \& Bayliss 2009, 68). However, here as well the number of cremations (over 50) suggests mortuary rites of a different character and scale once cremation was adopted as the dominant practice at these sites.

In Scotland, with the exception of regions of the far north, such as Orkney, cremation burials in the centuries pre-dating the Forteviot cemetery are exceptionally rare, as are those from the early 3rd millennium cal BC, with one or two exceptions (eg, Kinnes 1985, 41-2; Johnston 1997, 245). Deposition of cremated remains other than at the cemeteries outlined above are also scarcely known. In the wider region of Forteviot there are a handful of broadly contemporary burials, albeit from later phases of the Late Neolithic, but none is directly contemporary with Forteviot, generally being a century or more later in date. These include a cremation deposit found at Orwell, found near the top of the socket of one of two standing stones, which has been dated to $2890-2630$ cal BC $(95 \%$ confidence; SUERC-18309, $4180 \pm 35$ вр: Sheridan 2008, 201). 


\section{G. Noble \& K. Brophy. NEOLITHIC CREMATION CEMETERY, FORTEVIOT, PERTH \& KINROSS}

Elsewhere in mainland Scotland there is a single cremation deposit of an adult female discovered in a posthole re-cut on the middle palisade at Dunragit, Dumfries and Galloway, dated to 2869-2580 cal вС (95\% probability; SUERC-36378, $4125 \pm 30 \mathrm{BP}$ ) (McKinley 2015, 127-8; Thomas 2015, 145). Cremation deposits have also been identified at a Bronze Age cremation cemetery at Holly Road, Fife (Lewis \& Terry 2004) that pre-dated the Bronze Age horizons (ScARF 2012, section 3.3.1.2). There are also cremation deposits associated with timber monuments of late $4 \mathrm{th} /$ early 3rd millennium cal $\mathrm{BC}$ date, such as examples from Raigmore, Highland (Simpson 1996), and Beckton Farm, Dumfries \& Galloway (Pollard 1997), but these remain uncommon and isolated discoveries, and there is no evidence that such sites acted as cemeteries.

Thus it would appear that late 4th/early 3rd millennium cal BC cremation cemeteries were rare and the assemblages from Forteviot and Cairnpapple Hill unusual. The creation of these two cemeteries appears to be a new practice in lowland Scotland, and their similarity to cemeteries across Britain suggest change was occurring at key regional centres across this wider region by the turn of the millennium. This period marks a more general horizon of change across Britain associated with the adoption of Grooved Ware pottery, circular architecture, and a range of social practices sometimes labelled the 'Grooved Ware complex' (Eogan \& Roche 1993; Bradley 2007; Thomas 2010). Although artefacts found in association with cremation depositions are rare for this period, when they have been found they reinforce a connection with Grooved Ware traditions, for example, the transverse arrowheads and stone mace-heads from Dorchester-on-Thames and Stonehenge (Roe 1968; Eogan 1986, 138).

The changes associated with the introduction of the Grooved Ware complex have been connected to emergent social hierarchies. Both Thomas (1999, 153) and Jones (2008, 186), for example, have linked cremation cemeteries to the development of new networks between dispersed, yet pivotal, high status kin groups throughout Britain and Ireland towards the end of the late 4th millennium BC. Parker Pearson et al. (2009, 36) have gone further and suggested those buried at the Stonehenge cemetery were members of a 'ruling elite family' from a 'single dynasty' (ibid.).

We can certainly see that at a number of places across Neolithic Britain the establishment of a cremation cemetery was a key act in establishing important places. At many of the sites highlighted in this paper, the cremation cemeteries appear to mark key phases in the history of major monument complexes; they contain evidence of high investments in acts of place-making, which included the construction of some of the largest Neolithic monuments in Britain. The cremation cemeteries we know best, and the largest examples in particular, are almost all associated with extensive and long-lived monument complexes - Stonehenge, Dorchester-on-Thames, Llandygái, Forteviot, Balfarg/ Balbirnie, Duggleby Howe, and the recently identified sites at the Imperial College Sports Ground. Although the latter involved smaller numbers of cremations, they were located in the densest area of Neolithic monuments in the Middle Thames Valley, only a few kilometres from the impressive $3.5 \mathrm{~km}$ long bank barrow monument at Stanwell (Powell et al. 2015, 7).

In some (but not all) instances, the deposition of cremated remains is among the earliest activities that occurred in these places. At Forteviot, for example, cremation practices were clearly a transformative element in the significance of the lower Strathearn landscape in the early 3rd millennium cal BC. It appears the cemetery was last used in 2885-2650 cal $B C \quad 195 \%$ probability; end: Forteviot Cremation Cemetery), though small quantities of cremated human bone found within upper fills of the palisaded enclosure entrance avenue postholes (dated to 2580 2460 cal BC \& 2580-2465 cal BC, 95\% confidence; SUERC-45555, $3976 \pm 29$ BP; SUERC-45556, $3995 \pm$ $29 \mathrm{BP})$ suggests the burning of cremation pyres may have continued after the cremation cemetery identified at Henge 1 was no longer in use. In the centuries that followed, the Forteviot cemetery was enclosed by a palisaded enclosure, which was constructed c. 2800$2600 \mathrm{cal} \mathrm{BC}$ and decommissioned by $2565-2470 \mathrm{cal}$ BC ( $95 \%$ probability), and directly enclosed by a timber circle constructed in the period 2620-2475 cal вС (95\% confidence; mean of SUERC-23237 \& -23246, $4035 \pm 22 \mathrm{BP} ; \mathrm{T}^{\prime}=2.0, \nu=1, \mathrm{~T}^{\prime}(5 \%)=3.8:$ Ward $\&$ Wilson 1978; see Brophy \& Noble forthcoming). The cremation cemetery was later enclosed by a Chalcolithic henge monument (Brophy \& Noble 2012), probably in the period 2385-2270 cal BC $168 \%$ probability; start: Henge 1). The monuments found in the vicinity of the cremation cemetery are the most complex and represent the largest investment in labour (with the exception of the palisaded enclosure) identified at the Forteviot complex. While there may have been a gap between the establishment of the cremation cemetery and the construction of the later monuments, 
the superimposition of these enclosures and their focus on the cremation cemetery is compelling evidence that the cemetery remained known and important, and that its importance was restated again and again.

The enduring significance of cremation cemeteries, perhaps maintained by a combination of tangible markers alongside oral tradition, is evident elsewhere. For instance, at Llandygái Henge A, the location of various cremation deposits within and outside of the henge strongly suggests the monument here respected, and perhaps responded to, this early burial activity. At Stonehenge, Parker Pearson et al. (2009) note that the arrangement of the cremation cemetery complex was deeply implicated in the development of Stonehenge as a major monument, a place of the dead from its earliest inception. Where cremation cemeteries were not primary activities, but occurred in established monuments or monument complexes, they generally marked some kind of transformative, renewed phase of activity after a lengthy hiatus, as was the case at Duggleby Howe and Dorchester-on-Thames - all of these sites remained significant places through the Chalcolithic and into the Early Bronze Age.

\section{Places of transformation}

Despite monument and burial form varying through time at Forteviot, the character of architecture and activity appears to have been very much associated with the celebration and commemoration of the dead (Noble \& Brophy 2011). It could also be argued that successive circular monuments were built to contain or control access to the physical remains of the deceased, such as Henge 1 with its deep ditches, high banks, and narrow entrance way. Before this, the construction of the timber circle and the palisaded enclosure would have also defined particular ways of moving through and experiencing the location of the cemetery and its wider landscape setting. This growing emphasis on enclosure and control through time at Forteviot can also be identified at other cremation cemeteries. The timber/stone circle at Cairnpapple, for example, was replaced by a henge (Barclay 1999; Younger 2016), and a high henge bank was constructed at Stonehenge; in both cases these additions would have curtailed physical and visual access into the interiors. Similarly, at other cemeteries the construction of alternative monuments also combined different materials to create restricted visual and physical access. At Dorchester-on-Thames Site IV
(Atkinson et al. 1951, 39), for example, timber planks appear to have been set in the ditches which would have offered a visual barrier to activities within, while the close-set nature of the posts of the other timber circles constructed at Dorchester-on-Thames would also have created an architecture of containment (cf. Warner 2000; Barclay 2005; Bradley 2011).

Containing and restricting access to the dead may have been one way in which their remains were curated as an important resource for the living at these late 4th/early 3rd millennium cal BC cemeteries. Whether the dead themselves were transformed by the process of cremation at the same locations is uncertain, for the archaeological identification of pyre sites is notoriously difficult (McKinley 1997; 2013). The small fragments of cremated bone found in the upper fills of postholes at the avenue of the Forteviot palisaded enclosure could represent the location of nearby pyres, but we have no direct evidence for pyres themselves at Forteviot. Indeed, most of the sites discussed above were found in arable lowlands, subject to truncation by modern agriculture, adding to the difficulty in identifying where cremations actually happened. Experimental archaeology and observation of contemporary cremations suggests that even large funerary pyres may leave few or no tangible traces (cf. Downes 1999, 24). Circumstantially, at sites such as Dorchester-on-Thames (Site 3), it is possible that the destruction of that monument by fire may have been associated with the cremation process itself (Whittle et al. 1992, 174), but this cannot be proved. Evidence for redeposited pyre material is more commonly found; for instance, McKinley (1995, 461) noted that some of the cremations in the Aubrey Holes at Stonehenge included pyre debris. A series of 'black soils' identified in ditches and pits at Sites I, II, IV, V, and VI at Dorchester-on-Thames may have also been dumps of pyre material (contra Atkinson et al. 1951, 33 ), and probable pyre debris was also found at the ring ditches at Imperial College Sports Ground (Powell et al. 2015, 27). The places of transformation of the dead at these sites may not have been far removed from the places of final deposition.

In the same way that the bodies on the pyres were transformed through the act of cremation (Williams 2004; Brophy et al. forthcoming), the monuments associated with the deposition of cremated remains also appear to have witnessed episodes of transformation through time. At Forteviot (Brophy \& Noble 2012), Cairnpapple (Piggott 1948), and Stonehenge (Parker 


\section{G. Noble \& K. Brophy. NEOLITHIC CREMATION CEMETERY, FORTEVIOT, PERTH \& KINROSS}

Pearson et al. 2009) it has been suggested that a stone setting or even whole stone circles were dismantled during the life (or afterlife) of their use as places for the deposition of cremated remains. The evidence from Dorchester-on-Thames (cf. Gibson 1992) suggests that this happened during the active use of structures such as Site IV as places for the deposition of cremated remains in some cases remains of the dead were deposited in the voids left by dismantled posts and stone settings.

In these respects, both the monuments and the dead went through ritualised transitions, perhaps even rites of passage, which enabled the creation of new statuses and identities for the people interred and the places that the monuments defined (Hertz 1960, 29ff; van Gennep 1960). Destroying or removing upright stones and timbers may have been a physical manifestation of the transformation that bodily death entailed - part of the 'technologies of remembrance' used by some Neolithic communities to ensure the spectacular transformation of the dead into new categories of being (cf. Jones 2003). Acts such as these would have made the monuments places of dramatic transformation and sites worthy of remembrance.

\section{Genealogies of the dead}

Evidence from the late 4th/early 3rd millennium cal вс cremation cemeteries in Britain suggests that the dead and their commemoration were clearly an important part of the biography and development of some of the major Neolithic monument complexes of Britain. But who were the dead? As noted above, those afforded burials in these cemeteries could have been important individuals, though whether this was due to their status in life or due to the ways in which the living used the remains to create particular places of power (or both) is uncertain. Thomas $(1999,156)$ has argued that cremation practice and cemeteries were results of the increased importance of the individual and descent in late 4th/early $3 \mathrm{rd}$ millennium cal вс society. The establishment of cemeteries may have marked the formulation and importance of particular lineages within Neolithic society, and the monuments themselves may have been important places where the genealogies of important groups within particular regions were established through time (Parker Pearson et al, 2009, 36).

Some cremation cemeteries may also suggest the importance of particular individuals. At Llandygái, for example, the large henge enclosure appears to have surrounded the cremated remains of a single individual; additional burials were later added just outside of the henge (Lynch \& Musson 2001). The sequence here could be seen as a very direct way of expressing lineage and descent from a founding burial. Other monuments appear to show evidence for possible founding burials. At West Stow, for example, a crouched inhumation burial was found central to the ring ditch. A cremation deposit had been placed in the upper fill, and 48 others had been deposited around the edges of what may have been a small barrow that sealed the central inhumation and cremation (West 1989, 8-9). The double ditch ring ditch at Imperial College Sports Ground was centred around a central cremation deposit of a female and child which produced the earliest radiocarbon date for the site (Powell et al. 2015, 28).

Another possible indicator of the importance of individuals and their relationship to the collective dead is the effort made to collect the cremated remains for deposition. One striking element of the Forteviot cremations is the retention of very small bones: nearly all cremation deposits included tiny bones such as fingertips, wrist bones, small bones of the feet, and dental fragments. This demonstrates careful collection of remains from the pyre site. A similar collection strategy was also noted at Stonehenge (McKinley 1995, 459). The cremated remains from Forteviot and Stonehenge also suggest a high degree of 'pyre efficiency' - pyres were well-made and were clearly diligently maintained to ensure that they burned for an extended period at high temperatures (ibid.). The lack of wood charcoal and the clean nature of the cremated bones at Dorchester-on-Thames led Atkinson et al. (1951, 46-7) to suggest that the bones may have been very carefully selected prior to deposition. Such careful treatment in terms of cremation practice, bone collection, and preparation for deposition could be viewed as indicators of the status of the deceased (McKinley 1997), which in turn may bring into play other social concerns, such as dealing with taboo or venerated materials.

An unusual trait identified at Forteviot, but one that is evidenced at other cremation cemeteries (Table 5), was the relatively common deposition of mixed or grouped cremated remains (ie commingled deposits representing more than one individual). In an analysis of over 4000 prehistoric cremation deposits, McKinley (1997, 130) found only 5\% were of more than one individual. Yet at Forteviot, groups of cremated 
remains from multiple individuals were surprisingly common in secure contexts, notably adult/child pairings and small pit [651] containing four individuals. McKinley $(1994,100-2 ; 1997,142)$ notes that the pairing of an older individual with an immature person is the most commonly found multiple cremation deposit in her sample and she suggests these pairs were cremated together. However, the frequency of examples of the practice of the deposition of mixed or multiple cremations at Forteviot could also suggest that remains of individuals were 'curated' over time to allow simultaneous deposition. Strategies for this may have varied. Most of the cremated remains had a fresh appearance, meaning that the remains had been picked from the cremation pyres soon after burning, but the bone fragments found in context (560) had a 'bleached' or weathered appearance, suggesting that the remains may have lain exposed for some time before being collected. The generally fresh appearance of most remains could also mean that some cremation deposits were kept safe in containers (perhaps those in which they were eventually buried) prior to being deposited with other cremated remains at a later date. Here we can perhaps see parallels with the conjoined and multiple inhumation burials that occasionally occur in the late 4th to first half of the 3rd millennium cal BC (eg Jones 2008, 185-6; Healy 2012; Gibson 2016). Whether the individuals at Forteviot were related or not, it is in the act of commingling and depositing at particular locations within cemeteries that we can witness further ways in which burial may have been used to materialise particular genealogies or histories of the dead, and create, manipulate, and at times reimagine the dead's status, their relationships with the living, and the history of these communities.

The physical remains may also reveal more about the individual biographies of the dead. The Forteviot cremated remains, for example, included two younger individuals who appeared to have suffered weaning stress and one person who may have died due to cranial trauma, both evidence of divergent lifestyles. Of course other possibilities are conceivable - the presence of the potential cranial trauma could mean that at least some of the dead represented the remains of vanquished rival social group members or even the remains of a sacrificial underclass (Gibson \& Bayliss 2009, 73).

In terms of the importance of individual identities, it is also worth considering the grave goods that accompanied some individuals. In terms of numbers it is worth noting that grave goods were only associated with a limited number of individuals from the late 4th/ early 3rd millennium cal BC cremation cemeteries, with a preponderance of grave goods occurring in the earlier phases of burial activity. At Llandygái, for example, the central cremation burial was deposited with an axe-polishing stone, shells, and pottery sherds, and at West Stow, the central inhumation was placed with a stone bead. At Site II, Dorchester-on-Thames, one of the central burials in Pit B was deposited with a stone mace-head, a flint fabricator, and flake, and a bone pin, whereas the other individuals (MNI 20) scattered within the interior and in the ditch of the monument were buried with very little (Table 5). At Forteviot, only some of the burials were accompanied by bone pins and only one with a pottery vessel (in this case, a child).

One final intriguing trait of these late 4th/early 3rd millennium cal BC cremation cemeteries is the recurring association of human remains with bone 'skewer' pins. A total of eight or nine pins of this type were identified at Forteviot and, as mentioned already, similar pins have been found at Cairnpapple, Duggleby Howe, Stonehenge, Dorchester-on-Thames, and West Stow. The Stonehenge pins in particular, as described by Montague (1995), display striking similarities in both form and dimensions to the Forteviot assemblage (see Sheridan, above). The calcined state of these pins suggests they were placed on the pyre with the dead, either in the form of a shroud pin, an item of decoration, jewellery, or as a clothing/hair accessory (Kinnes et al. 1983). It could even be argued that such pins were part of the formal dress worn by important people at this time; if not, it certainly seems likely that they were an element in the display of particular individuals on the funerary pyre. Few other grave good types are known, but there are some exceptional finds, such as the axe-polishing stone at Llandygái and the mace-heads from Site II at Dorchester-on-Thames and Stonehenge. The presence of a possible incense burner buried with one individual at Stonehenge has led Parker Pearson $(2012,201,205)$ to suggest some of the deceased may have been religious specialists; the chafing vessel from Forteviot could be interpreted similarly.

Whether the individuals placed in late 4th/early 3rd millennium cal BC cremation cemeteries were special or powerful remains to be seen. Nonetheless, we can see how the creation of cemeteries and the human remains contained within may have helped to establish the 


\section{G. Noble \& K. Brophy. NEOLITHIC CREMATION CEMETERY, FORTEVIOT, PERTH \& KINROSS}

importance of particular lineages across Britain in this period, creating histories that would have been made more memorable through the dramatic and transformative act of cremation itself (Williams 2004; Sörenson \& Bille 2008).

\section{CONCLUSION}

The late 4th/early 3rd millennium cal $\mathrm{BC}$ cremation cemeteries of Britain are now obtaining the attention they deserve, as a consequence of some remarkable recent discoveries and our increasingly refined chronologies. The evidence from sites such as Forteviot has given us insight into burial rites, social change, placemaking, and power strategies during a significant period of transition in lowland Scotland, which was part of a broader period of change in the late 4th/early 3rd millennium cal $\mathrm{BC}$; the dating evidence and new analysis presented here suggests the importance of the 31st and 30th centuries cal BC, when major cemeteries such as Stonehenge, Balbirnie, and Forteviot were created. Across Britain, many major monument complexes were established anew or re-invigorated around this time, and the establishment of cremation cemeteries at these major sites is an increasingly recognised phenomenon in our considerations of the changes that ushered in later Neolithic society. The significance of cemeteries such as Forteviot goes beyond the simple detail of an important regional example. It emphasises the connections between communities across Britain in this period and the potential motivations that led to the development of particular major monument complexes. These cemeteries also give us insights into how particular social and political constitutions were legitimised and what may have been the consequences of their creation at this particular juncture in prehistory (Lewis 1962, 35). At Forteviot and Stonehenge, the act of creating the cremation cemetery appears to have established the conditions for major ceremonial centres to develop and thrive over a period of more than 1000 years - these were small acts of deposition with a monumental, long-term resonance.

Acknowledgements: This paper is the result of the hard work and contributions of many people. In particular, we would like to thank the substantial contributions made to this paper by Alison Sheridan, Stephany Leach, and Derek Hamilton; they also kindly read over and commented on earlier versions of this paper. All errors remain our own. The excavations at Forteviot were the work of dozens of students from Glasgow and Aberdeen Universities and local volunteers. Dupplin Estate kindly allowed us to work at Forteviot. Fieldwork and post-excavation analysis was largely funded by Historic Environment Scotland (then Historic Scotland), and we very much benefited from the support of colleagues within the SERF Project - Ewan Campbell, Steve Driscoll, and Tessa Poller. Figs 1 \& 2 were prepared by Lorraine McEwan, while Figs 3, 17, \& 18 were drawn by Alison Sandison. Figs 9-16 were prepared by Derek Hamilton, while the drawings in Figs $7 \&$ 8 were undertaken by Marion O’Neil. Historic Environment Scotland have provided grant aid for the publication and illustration of this paper.

\section{BIBLIOGRAPHY}

Atkinson, R.J.C., Piggott, C.M. \& Sanders, N.K. 1951. Excavations at Dorchester, Oxon. Oxford: Ashmolean Museum

Ashmore, P.J. 1999. Radiocarbon dating: Avoiding errors by avoiding mixed samples. Antiquity 27(279), 124-30

Barclay, G.J. 1999. Cairnpapple revisited: 1948-1998. Proceedings of the Prehistoric Society 65, 17-46

Barclay, G.J. 2003. The Neolithic. In I. Ralston \& K. Edwards (eds), Scotland after the Ice Age. Environment, Archaeology and History, 8000 BC - AD 1000, 127-50. Edinburgh: Edinburgh University Press

Barclay, G.J. 2005. The 'henge' and 'hengiform' in Scotland. In V. Cummings \& A. Pannett (eds), Set in Stone: New approaches to Neolithic monuments in Scotland, 81-95. Oxford: Oxbow Books

Barclay, G.J. \& Russell-White, C.J. 1993. Excavations in the ceremonial complex of the fourth to third millennium $\mathrm{BC}$ at Balfarg/Balbirnie, Glenrothes, Fife. Proceedings of the Society of Antiquaries of Scotland 123, 43-110

Bradley, R. 2007. The Prehistory of Britain and Ireland. Cambridge: Cambridge University Press

Bradley, R. 2011. Stages and Screens: An investigation into henge monuments in northern and north-eastern Scotland. Edinburgh: Society of Antiquaries of Scotland

Bronk Ramsey, C. 1995. Radiocarbon calibration and analysis of stratigraphy: The OxCal program. Radiocarbon 37(2), 425-30

Bronk Ramsey, C. 1998. Probability and dating. Radiocarbon 40(1), 461-74

Bronk Ramsey, C. 2001. Development of the radiocarbon calibration program. Radiocarbon 43(2A), 355-63

Bronk Ramsey, C. 2009. Bayesian analysis of radiocarbon dates. Radiocarbon 51(1), 337-60

Brophy, K. 2016. On ancient farms: Neolithic settlement in mainland Scotland. In Brophy et al. 2016, 200-35

Brophy, K. \& Noble, G. 2012. Henging, mounding and blocking: The Forteviot henge group. In A. Gibson (ed.), Enclosing the Neolithic: Recent studies in Britain and Europe, 21-35. Oxford: British Archeological Report S2440

Brophy, K. \& Noble, G. forthcoming. Prehistoric Forteviot: SERF excavations 2007-2010. York: Council for British Archaeology

Brophy, K., MacGregor, G. \& Noble, G. forthcoming. Warm air and glowing pyres: Cremating bodies in the Late 
Neolithic of Scotland. In P. Bickle \& E. Sibbesson (eds), Neolithic Bodies. Oxford: Oxbow Books

Brophy, K., MacGregor, G. \& Ralston, I. (eds). 2016. The Neolithic of Mainland Scotland. Edinburgh: Edinburgh University Press

Brickley, M. \& McKinley, J.I. (eds). 2004. Guidelines to the Standards for Recording Human Remains. Reading: IFA Paper 7

Buck, C.E., Cavanagh, W.G. \& Litton, C.D. 1996. Bayesian Approach to Interpreting Archaeological Data. Chichester: Wiley

Buck, C.E., Kenworthy, J.B., Litton, C.D. \& Smith, A.F.M. 1991. Combining archaeological and radiocarbon information: A Bayesian approach to calibration. Antiquity 65, 808-21

Byers, S.N. 2005. Introduction to Forensic Anthropology: A textbook. Boston: Allyn \& Bacon

Cleal, R.M.J., Walker, K.E. \& Montague, R. 1995. Stonehenge in its Landscape: Twentieth-century excavations. London: English Heritage

Cooney, G. 2016. Pathways to ancestral worlds: Mortuary practice in the Irish Neolithic. In Brophy et al. 2016, 79-94

Darvill, T.C., Marshall, P., Parker Pearson, M. \& Wainwright, G.J. 2012. Stonehenge remodeled. Antiquity $86,1021-40$

Downes, J. 1999. Cremation: A spectacle and a journey. In J. Downes \& T. Pollard (eds), The Love'd Body's Corruption, 19-29. Glasgow: Cruithne Press

Driscoll, S.T. 1998. Picts and prehistory: Cultural resource management in early medieval Scotland. World Archaeology 30(1), 142-58

Driscoll, S.T., Brophy, K. \& Noble, G. 2010. The Strathearn Environs and Royal Forteviot Project (SERF). Antiquity Project Gallery. Available at: http://antiquity.ac.uk/ projgall/driscoll323/ [Last accessed 6 May 2016]

Dunbar, E.T., Cook, C.G., Naysmith, P., Tripney, B.G. \& $\mathrm{Xu}$, S. 2016. AMS ${ }^{14} \mathrm{C}$ dating at the Scottish Universities Environmental Research Centre (SUERC) Radiocarbon Dating Laboratory. Radiocarbon 58(1), 9-23

Eogan, G. 1986. Knowth. London: Thames \& Hudson

Eogan, G. \& Roche, H. 1993. Neolithic ritual at Knowth? Archaeology Ireland 26, 16-18

Gardiner, J. 1995. Artefacts and ecofacts: The finds assemblage. In Cleal et al. 1995, 348-67

Garwood, P. \& Barclay, A. 2011. Making the dead. In Morigi et al. 2011, 383-432

Gibson, A. 1992. Possible timber circles at Dorchester-onThames. Oxford Journal of Archaeology 11(1), 85-91

Gibson, A.M. 1994. Excavations at the Sarn-y-bryn-caled cursus complex, Welshpool, Powys, and the timber circles of Great Britain and Ireland. Proceedings of the Prehistoric Society 60, 143-224

Gibson, A.M. 2004. Small but perfectly formed? Some observations on the Bronze Age cups of Scotland. In A. Gibson \& A. Sheridan (eds), From Sickles to Circles: Britain and Ireland in the time of Stonehenge, 270-88. Tempus: Stroud

Gibson, A. 2010a. Dating Balbirnie: Recent radiocarbon dates from the stone circle and cairn at Balbirnie, Fife, and a review of its place in the overall Balfarg/Balbirnie site sequence. Proceedings of the Society of Antiquaries of Scotland 140, 51-77

Gibson, A. 2010b. New dates for Sarn-y-bryn-caled, Powys, Wales. Proceedings of the Prehistoric Society 76, 351-6

Gibson, A. 2016. Who were these people? A sideways view and a non-answer of political proportions. In Brophy et al. 2016, 57-73

Gibson, A. \& Bayliss, A. 2009. Recent research at Duggleby Howe, North Yorkshire. Archaeological Journal 166, 39-78

Gibson, A., Allen, M., Bradley, P., Carruthers, W., Challinor, D., French, C., Hamilton, D., Mainland, I., McCarthy, M., Ogden, A., Scaife, R., Sheridan, A. \& Walmsley, C. 2011. Report on the Excavation at the Duggleby Howe causewayed enclosure, North Yorkshire, May-July 2009. Archaeological Journal 168, 1-63

Gurdjian, E.S., Webster, J.E. \& Lissner, H.R. 1950. The mechanism of skull fracture. Radiology 54, 313-39

Hawley, W. 1921. The excavations at Stonehenge. Antiquaries Journal 1, 19-39

Healy, F. 2012. Chronology, corpses, ceramics, copper and lithics. In M.J. Allen, J. Gardiner \& A. Sheridan (eds), Is there a British Chalcolithic? People, place and polity in the later 3rd millennium, 144-63. Oxford: Prehistoric Society Research Paper 4

Hertz, R. 1960. Death and the Right Hand. New York: Free Press

Johnston, D.A. 1997. Biggar Common, 1987-1993: An early prehistoric funerary and domestic landscape in Clydesdale, South Lanarkshire. Proceedings of the Society of Antiquaries of Scotland 127, 185-253

Jones, A.M. 2003. Technologies of remembrance: Memory, materiality and identity in Early Bronze Age Scotland. In H. Williams (ed.), Archaeologies of Remembrance: Death and memory in past societies, 65-88. New York: Kluwer Academic/Plenum

Jones, A. 2008. How the dead live: Mortuary practices, memory and the ancestors in Neolithic and Early Bronze Age Britain and Ireland. In J. Pollard (ed.), Prehistoric Britain, 177-201. Oxford: Blackwell

Jones, E., Sheridan, A., Smith, A. \& Franklin, J. in press. Pots, pits and roundhouses: Neolithic and Bronze Age occupation at Meadowend Farm, Clackmannanshire. Scottish Archaeological Internet Reports

Kaufman, M.H., Whitaker, D. \& McTavish, J. 1997. Differential diagnosis to holes in the calvarium: Application of modern clinical data to paleopathology. Journal of Archaeological Science 24, 193-218

Kinnes, I. 1979. Round Barrows and Ring-ditches in the British Neolithic. London: British Museum Occasional Paper 7

Kinnes, I. 1985. Circumstance, not context: The Neolithic of Scotland as seen from the outside. Proceedings of the Society of Antiquaries of Scotland 115, 15-57

Kinnes, I., Schadla-Hall, T., Chadwick, P. \& Dean, P. 1983. Duggleby Howe reconsidered. Archaeological Journal 140, 83-108

Knüsel, C.J. \& Outram, A.K. 2004. Fragmentation: The zonation method applied to fragmented human remains 


\section{G. Noble \& K. Brophy. NEOLITHIC CREMATION CEMETERY, FORTEVIOT, PERTH \& KINROSS}

from archaeological contexts. Environmental Archaeology 9, 85-97

Leach, S. 2012. Report on the Human Skeletal Remains Excavated from the Prehistoric Ceremonial Complex Site at Forteviot, Perthshire (2008-2010). Unpublished report for the SERF Project

Lee, S. \& Bronk Ramsey, C. 2012. Development and application of the trapezoidal model for archaeological chronologies. Radiocarbon 54(1), 107-22

Lewis, I.M. 1962. Historical aspects of geneaologies in Northern Somali social structure. Journal of African History 3(1), 35-48

Lewis, J. \& Terry, J. 2004. The excavation of an Early Bronze Age cemetery at Holly Road, Leven, Fife. Tayside \& Fife Archaeological Journal 10, 23-53

Lynch, F. \& Musson, C. 2001. A prehistoric and early medieval complex at Llandegai, near Bangor, north Wales. Archaeologia Cambrensis 150, 17-142

McKinley, J.I. 1993. Bone fragment size and weights of bone from modern British cremations and its implications for the interpretation of archaeological cremations. International Journal of Osteoarchaeology 3, 283-87

McKinley, J.I. 1994. The Anglo-Saxon Cemetery at Spong Hill, North Elmham Part VIII: The cremations. East Dereham: East Anglian Archaeology 69

McKinley, J.I. 1995. Human bone. In Cleal et al. 1995, 451-60

McKinley, J.I. 1997. Bronze Age 'barrows', funerary rites and rituals of cremation. Proceedings of the Prehistoric Society 63, 129-46

McKinley, J.I. 2000. The analysis of cremated bone. In M. Cox \& S. Mays (eds), Human Osteology in Archaeological and Forensic Science, 403-21. London: Greenwich Medical Media

McKinley, J. 2013. Cremation: Excavation, analysis and interpretation of material from cremation relatedcontexts. In L.N. Stutz \& S. Tarlow (eds), The Oxford Handbook of the Archaeology of Death and Burial, 147-72. Oxford: Oxford University Press

McKinley, J. 2015. Cremated bone. In Thomas (ed.) 2015, 127-31

Morigi, A., Schreve, D., White, M. \& Hey, G. 2011. Thames Through Time: The archaeology of the gravel terraces of the upper and middle Thames: Early prehistory to 1500 BC. Oxford: Oxford Archaeology

Montague, R. 1995. Bone and antler small objects. In Cleal et al. 1995, 407-14

Montague, R. \& Gardiner, J. 1995. Other stone. In Cleal et al. 1995, 390-99

Mortimer, J.R. 1905. Forty Years' Researches in British and Saxon Burial Mounds of East Yorkshire. London: A. Brown \& Sons

Naysmith, P., Cook, G., Freeman, S., Scott, E.M., Anderson, R., Dunbar, E., Muir, G., Dougans, A., Wilcken, K., Schnabel, C., Russell, N., Ascough, P. \& Maden, C. 2010. ${ }^{14} \mathrm{C}$ AMS at SUERC: Improving QA data from the $5 \mathrm{MV}$ tandem AMS and $250 \mathrm{kV}$ SSAMS. Radiocarbon 52(2), 263-71

Noble, G. \& Brophy, K. 2011. Ritual and remembrance at a prehistoric ceremonial complex in central
Scotland: Excavations at Forteviot, Perth and Kinross. Antiquity 85, 787-804

Parker Pearson, M. 2012. Stonehenge: Exploring the greatest Stone Age mystery. London: Simon \& Schuster

Parker Pearson, M., Chamberlain, A., Jay, M., Marshall, P., Pollard, J., Richards, C., Thomas, J., Tilley, C. \& Welham, K. 2009. Who was buried at Stonehenge? Antiquity 83, 23-39

Parker Pearson, M., Cleal, R., Marshall, P., Needham, S., Pollard, J., Richards, C., Ruggles, C., Sheridan, A., Thomas, J., Tilley, C., Welham, K., Chamberlain, A., Chenery, C., Evans, J., Knüsel, C., Linford, N., Martin, L., Montgomery, J., Payne, A. \& Richards, M. 2007. The age of Stonehenge. Antiquity 81, 617-39

Piggott, S. 1948. The Excavations at Cairnpapple Hill, West Lothian. Proceedings of the Society of Antiquaries of Scotland 82, 68-123

Piggott, S. 1954. The Neolithic Cultures of the British Isles. Cambridge: Cambridge University Press

Pollard, T. 1997. Excavations of a Neolithic settlement and ritual complex at Beckton Farm, Lockerbie, Dumfries and Galloway. Proceedings of the Society of Antiquaries of Scotland 127, 69-121

Powell, A.B., Barclay, A.J., Mepham, L. \& Stevens, C.J. 2015. Imperial College Sports Ground and RMC land, Harlington: The development of prehistoric and later communities in the Colne Valley and on the Heathrow terrace. Salisbury: Wessex Archaeology

Reimer, P.J., Bard, E., Bayliss, A., Beck, J.W., Blackwell, P.G., Bronk Ramsey, C., Buck, C.E., Chenge, H., Edwards, R.L, Friedrich, M., Grootes, P.M., Guilderson, T.P., Haflidason, H., Hajdas, I., Hatté, C., Heaton, T.J., Hoffmann, D.L., Hogg, A.G., Hughen, K.A., Kaiser, K.F., Kromer, B., Manning, S.W., Niu, M., Reimer, R.W., Richards, D.A., Scott, E.M., Southon, J.R., Staff, R.A., Turney, C.S.M. \& van der Plicht, J. 2013. Intcal 13 and marine13 radiocarbon age calibration curves $0-50,000$ years cal BP. Radiocarbon 55, 1869-87

Ritchie, J.N.G. 1974. Excavation of the stone circle and cairn at Balbirnie, Fife. Archaeological Journal 131, 1-32

Roberts, C.A. \& Cox, M. 2003. Health and Disease in Britain: From prehistory to the present day. Stroud: Sutton

Roe, F. 1968. Stone mace-heads and the latest Neolithic cultures of the British Isles. In J.M. Coles \& D.D.A. Simpson (eds), Studies in Ancient Europe: Essays presented to Stuart Piggott, 145-72. Leicester: Leicester University Press

Scott, E.M. 2003. The Third International Radiocarbon Intercomparison (TIRI) and the Fourth International Radiocarbon Intercomparison (FIRI) 1990-2002: Results, analysis, and conclusions. Radiocarbon 45, 135-408

St Joseph, J.K. 1976. Air reconnaissance: Recent results, 40. Antiquity 50, 55-7

Sheridan, J.A. 2007. Dating the Scottish Bronze Age: 'there is clearly much that the material can still tell us'. In C. Burgess, P. Topping \& F. Lynch (eds), Beyond Stonehenge: Essays on the Bronze Age in honour of Colin Burgess, 162-85. Oxford: Oxbow Books

Sheridan, J.A. 2008. Radiocarbon dates arranged through National Museums of Scotland Archaeology Department 
during 2007/8. Discovery and Excavation Scotland 9(new series), 201-2

Sheridan, J.A., Bradley, R. \& Schulting, R. 2009. Radiocarbon dates arranged through National Museums of Scotland Archaeology Department during 2008/9. Discovery and Excavation Scotland 10(new series), 214-16 ScARF. 2012. Neolithic Scotland: Scottish Archaeological Research Framework Panel Report. Edited by J.A. Sheridan \& K. Brophy. Available at: http://www. scottishheritagehub.com/content/panel-report-chronologyand-downloads [Last accessed 9 May 2016]

Simpson, D.D.A. 1996. Excavation of a kerbed funerary monument at Stoneyfield, Raigmore, Inverness, Highland, 1972-3. Proceedings of the Society of Antiquaries of Scotland 126, 53-86

Sőrensen, T.F. \& Bille, M. 2008. Flames of transformation: The role of fire in cremation practices. World Archaeology 40(2), 253-67

Steier, P. \& Rom, W. 2000. The use of Bayesian statistics for ${ }^{14} \mathrm{C}$ dates of chronologically ordered samples: A critical analysis. Radiocarbon 42, 183-98

Stuiver, M. \& Kra, R.S. 1986. Editorial comment. Radiocarbon 28(2B), ii

Stuiver, M. \& Polach, H.A. 1977. Reporting of ${ }^{14} \mathrm{C}$ data. Radiocarbon 19, 355-63

Stuiver, M. \& Reimer, P.J. 1986. A computer program for radiocarbon age calculation. Radiocarbon 28, 1022-30

Stuiver, M. \& Reimer, P.J. 1993. Extended ${ }^{14} \mathrm{C}$ data base and revised CALIB $3.0{ }^{14} \mathrm{C}$ age calibration program. Radiocarbon 35, 215-30

Thomas, J. 1999. Understanding the Neolithic. London: Routledge

Thomas, J. 2010. The return of the Rinyo-Clacton folk? The cultural significance of the Grooved Ware complex in Late Neolithic Britain. Cambridge Archaeological Journal 20(1), 1-15
Thomas, J. (ed.) 2015. A Neolithic Ceremonial Complex in Galloway: Excavations at Dunragit and Droughduil, 1999-2002. Oxford: Oxbow Books

van Gennep, A. 1960. Rites of Passage. London: Routledge

West, S. 1989. West Stow, Suffolk: The prehistoric and Romano-British occupations. Ipswich: East Anglian Archaeology 48

Ward, G.K. \& Wilson, S.R. 1978. Procedures for comparing and combining radiocarbon age determinations: $\mathrm{A}$ critique. Archaeometry 20, 19-32

Warner, R.B. 2000. Keeping out the otherworld: The internal ditch at Navan and other 'Iron Age' hengiform enclosures. Emania 18, 39-44

Whittle, A., Atkinson, R.J.C., Chambers, R., Thomas, N., Harman, M., Northover, P. \& Robinson, M. 1992. Excavations in the Neolithic and Bronze Age complex at Dorchester-on-Thames, Oxfordshire, 19471952 and 1981. Proceedings of the Prehistoric Society 58, 143-201

Williams, H. 2004. Death warmed up: The agency of bodies and bones in early Anglo-Saxon cremation rites. Journal of Material Culture 9(2), 263-91

Willis, C., Marshall, P., McKinley, J., Pitts, M., Pollard, J., Richards, C., Richards, J., Thomas, J., Waldron, T., Welham, K. \& Parker Pearson, M. 2016. The dead of Stonehenge. Antiquity 90, 337-56

Woodward, P.J. 1988. Pictures from the Neolithic: Discoveries from the Flagstones House excavations, Dorchester, Dorset. Antiquity 62, 266-74

Xu, S., Anderson, R., Bryant, C., Cook, G.T., Dougans, A., Freeman, S., Naysmith, P., Schnabel, C. \& Scott, E.M. 2004. Capabilities of the new SUERC 5MV AMS facility for ${ }^{14} \mathrm{C}$ dating. Radiocarbon 46(1), 59-64

Younger, R. 2016. Making memories, making monuments: Changing understandings of henges in prehistory and the present. In Brophy et al. 2016, 116-38

\section{RÉSUMÉ}

Pratiques d'incinération et la création des complexes monumentaux: Le cimetière à incinération néolothique de Forteviot, Strathearn, Perth et Kinross, Ecosse et ses comparables de Gordon Noble et Kenneth Brophy

Aux alentours du début du 3ème millénaire av.J.-C cal un cimetière à incinération fut établi à Forteviot, centre de l'Ecosse, RU. Ce lieu devait devenir l'un des plus grands complexes monumentaux jamais identifiés en Ecosse continentale, avec la construction d'un enclos à palissade, de structures en bois de construction et d'une série de monuments à talus et fossé et autres enceintes. Le cimetière fut établi entre 3080 av. J.-C. et 2900 av.J.-C.cal, probablement au 30ème siècle av.J.-C. cal, ce qui est contemporain du cimetière à incinération de Stonehenge. Neuf dépôts diffus d'os calcinés, représentant les restes d'au moins 18 personnes, furent identifiés. Dans la plupart des cas, ils se trouvaient à l'intérieur de structures creusées et, dans un des cas, une série de dépôts d'incinérations étaient associée à une pierre dressée cassée. Cet article inclut la première évaluation détaillée des restes incinérés de Forteviot et des indices associés au cimetière et explore comment l' établissement de ce cimetière a pu être à la fois un catalyste et une inspiration pour la construction de ce monument élaboré et les actes prolongés de mémoire qui s'y déroulèrent sur une période de presque 1000 ans. L'article décrit aussi les parallèles de Forteviot à travers la Grande-Bretagne et rassemble, pour la première fois, les témoignages de datations (y compris la modélisation bayésienne) de cette catégorie majeure de témoignages pour l'étude de la nature de la société de la fin du 4ème/début du 3ème millénaire av. J,-C. cal. Les résultats et la discussion ont de 


\section{G. Noble \& K. Brophy. NEOLITHIC CREMATION CEMETERY, FORTEVIOT, PERTH \& KINROSS}

vastes implications et résonances pour la reflexion sur l'établissement et l'évolution des complexes monumentaux dans la Grande-Bretagne préhistorique et au-delà.

\section{ZUSAMMENFASSUNG}

Praktiken der Leichenverbrennung und die Schaffung monumentaler Komplexe: Der neolithische Brandbestattungsplatz von Forteviot, Strathearn, Perth und Kinross, Schottland, und seine Komparanda, von Gordon Noble und Kenneth Brophy

Am Beginn des 3. Jahrtausends cal BC wurde ein Brandbestattungsplatz in Forteviot in Zentralschottland, Großbritannien, angelegt. Dieser Platz entwickelte sich zu einem der größten Komplexe mit Bestattungsmonumenten, den wir auf dem schottischen Festland kennen, mit der Konstruktion eines Erdwerkes mit Palisade, Holzstrukturen und einer Reihe von Henge-Monumenten und anderen Grabenwerken. Der Bestattungsplatz wurde zwischen 3080 und 2900 cal BC eingerichtet, wahrscheinlich im 30. Jahrhundert cal BC, was zeitgleich mit dem Brandbestattungsplatz von Stonehenge ist. Neun separate Deponierungen verbrannter Knochen wurden identifiziert, die die Überreste von mindestens 18 Personen repräsentieren. In den meisten Fällen fanden sie sich innerhalb eingetiefter Befunde, in einem Fall war auch eine Reihe von Deponierungen von Leichenbrand mit einem zerbrochenen Menhir assoziiert. Dieser Beitrag umfasst auch die erste detaillierte Auswertung der Leichenbrände von Forteviot sowie der mit dem Brandbestattungsplatz assoziierten Befunde und untersucht, wie die Einrichtung dieses Bestattungsplatzes sowohl ein Katalysator als auch eine Inspiration für das Errichten elaborierter Monumente und für fortgesetzte Akte des Gedenkens gewesen sein kann, die an diesem Platz über einen Zeitraum von fast 1000 Jahren stattfanden. Zudem zeigt der Beitrag die Parallelen für Forteviot in Großbritannien auf und bringt erstmals die Datierungen (einschließlich Bayesscher Modellierung) für diese zentrale Kategorie archäologischer Daten zur Erörterung des Charakters der Gesellschaft des späten 4./ frühen 3. Jahrtausends BC zusammen. Die Resultate und Diskussionen haben weitreichende Bedeutung für Überlegungen zur Entstehung und Entwicklung von Komplexen von Monumenten im prähistorischen Großbritannien und darüber hinaus.

\section{RESUMEN}

Prácticas de cremación y la creación de complejos monumentales: el cementerio de cremación de Forteviot, Strathearn, Perth y Kinross, y sus comparaciones, por Gordon Noble y Kenneth Brophy

Aproximadamente a principios del III milenio cal BC se estableció un cementerio de cremación en Forteviot, Escocia central, Reino Unido. Este emplazamiento llegó a ser uno de los complejos monumentales más grandes identificados en el interior de Escocia, con la construcción de un recinto empalizado, estructuras de madera y una serie de recintos y henge. El cementerio se estableció entre el 3080 y el 2900 cal BC, probablemente en el III milenio cal BC, por lo que es contemporáneo al cementerio de cremación de Stonehenge. Se han identificado nueve depósitos individualizados de hueso quemado, que representan los restos de, al menos, 18 personas. En la mayoría de los casos, se localizaron dentro de estructuras recortadas y, en un caso, una serie de depósitos de cremación estaba asociada a un hito de piedra quebrado. Este artículo incluye la primera evaluación detallada de los restos cremados de Forteviot y de las características relacionadas con el cementerio, y analiza cómo el establecimiento de este cementerio pudo haber sido un catalizador y una inspiración para la compleja construcción monumental y para los prolongados actos de conmemoración que ocurrieron en este lugar durante un periodo de al menos 1000 años. El artículo también señala los paralelos de Forteviot a lo largo de Gran Bretaña y, por primera vez, aúna la evidencia cronológica (incluyendo la modelización bayesiana) para este importante tipo de evidencia en el seno de la sociedad de finales del IV e inicios del III milenio cal BC. Los resultados y la discusión tienen una amplia implicación y relevancia para reflexionar sobre el establecimiento y la evolución de los complejos monumentales en la Prehistoria de Gran Bretaña y de fuera de ella. 